\title{
LEVEL II SCOUR ANALYSIS FOR BRIDGE 4 (ARLITH00010004) on TOWN HIGHWAY 1, crossing WARM BROOK, ARLINGTON, VERMONT
}

U.S. Geological Survey Open-File Report 97-182

Prepared in cooperation with

VERMONT AGENCY OF TRANSPORTATION and

FEDERAL HIGHWAY ADMINISTRATION 


\section{LEVEL II SCOUR ANALYSIS FOR BRIDGE 4 (ARLITH00010004) on TOWN HIGHWAY 1, crossing WARM BROOK, ARLINGTON, VERMONT}

By SCOTT A. OLSON and MICHAEL A. IVANOFF

U.S. Geological Survey Open-File Report 97-182

Prepared in cooperation with

VERMONT AGENCY OF TRANSPORTATION

and

FEDERAL HIGHWAY ADMINISTRATION 


\title{
U.S. DEPARTMENT OF THE INTERIOR BRUCE BABBITT, Secretary
}

\author{
U.S. GEOLOGICAL SURVEY \\ Gordon P. Eaton, Director
}

For additional information write to:

District Chief

U.S. Geological Survey 361 Commerce Way

Pembroke, NH 03275-3718
Copies of this report may be purchased from:

U.S. Geological Survey

Branch of Information Services

Open-File Reports Unit

Box 25286

Denver, CO 80225-0286 


\section{CONTENTS}

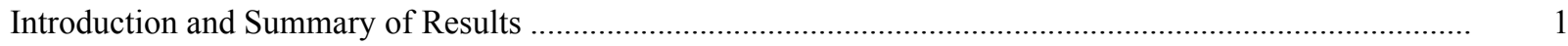

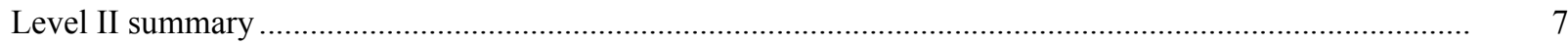

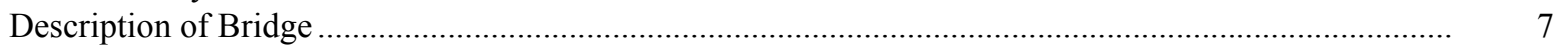

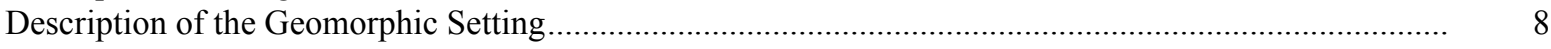

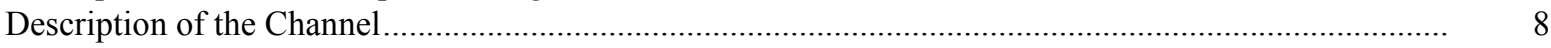

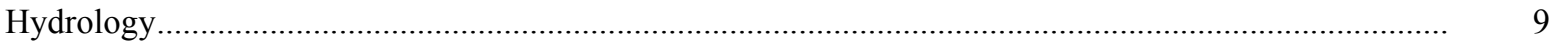

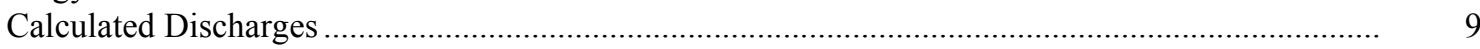

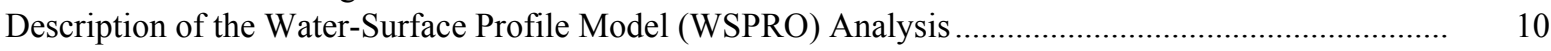

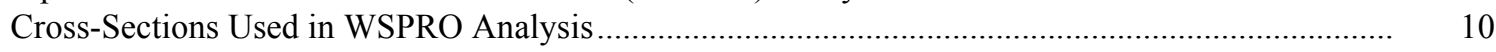

Data and Assumptions Used in WSPRO Model ...................................................................... 11

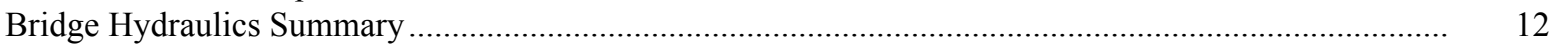

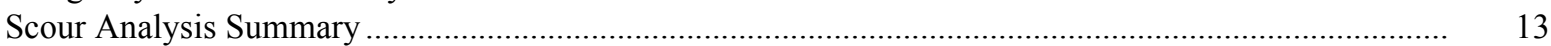

Special Conditions or Assumptions Made in Scour Analysis ...................................................... 13

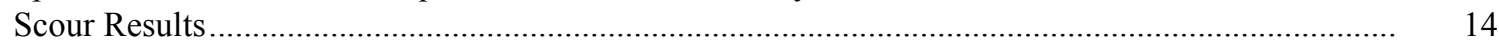

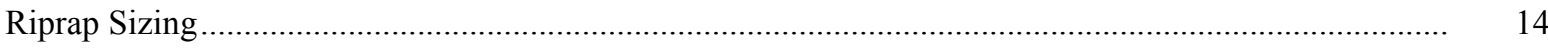

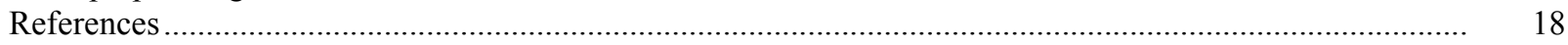

Appendixes:

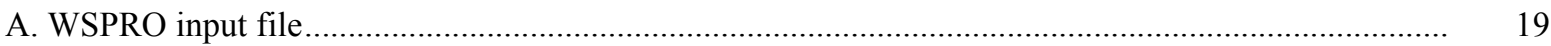

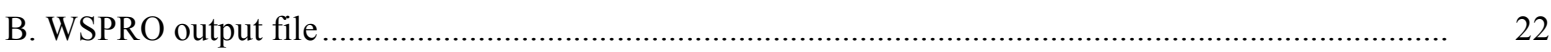

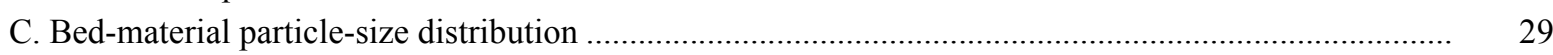

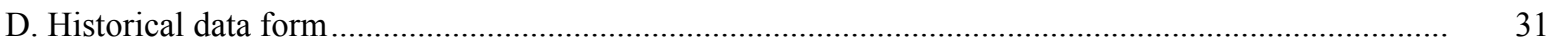

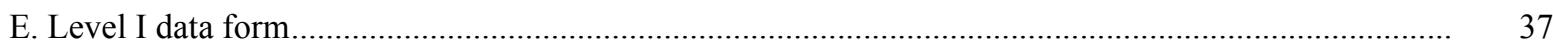

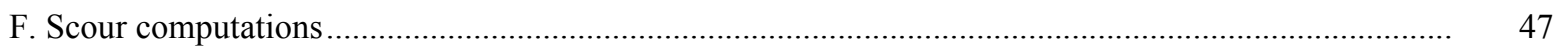

\section{FIGURES}

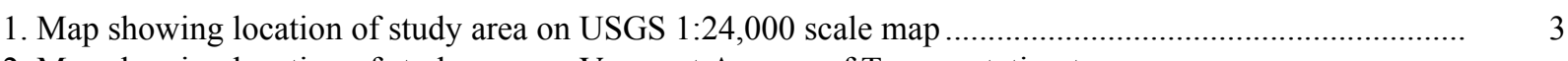

2. Map showing location of study area on Vermont Agency of Transportation town

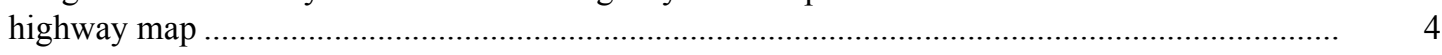

3. Structure ARLITH00010004 viewed from upstream (July 30, 1996) ....................................................

4. Downstream channel viewed from structure ARLITH00010004 (July 30, 1996). ................................ 5

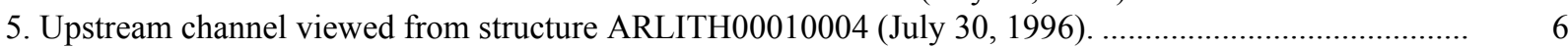

6. Structure ARLITH00010004 viewed from downstream (July 30, 1996).......................................... 6

7. Water-surface profiles for the 100- and 500-year discharges at structure

ARLITH00010004 on Town Highway 1, crossing Warm Brook,

Arlington, Vermont.

8. Scour elevations for the 100- and 500-year discharges at structure

ARLITH00010004 on Town Highway 1, crossing Warm Brook,

Arlington, Vermont.

\section{TABLES}

1. Remaining footing/pile depth at abutments for the 100-year discharge at structure

ARLITH00010004 on Town Highway 1, crossing Warm Brook,

Arlington, Vermont....

2. Remaining footing/pile depth at abutments for the 500-year discharge at structure

ARLITH00010004 on Town Highway 1, crossing Warm Brook,

Arlington, Vermont. 


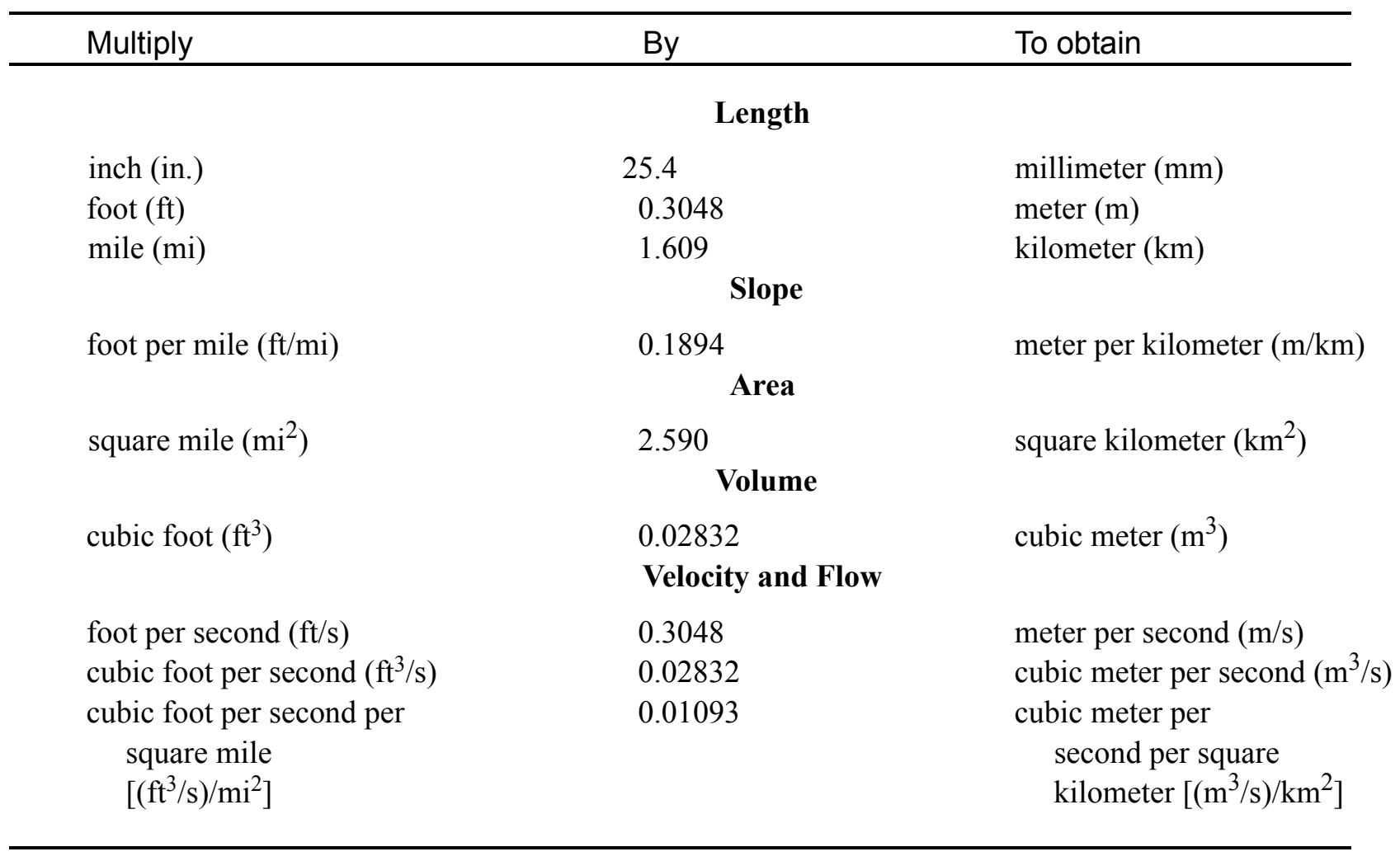

\section{OTHER ABBREVIATIONS}

$\begin{array}{lrlr}\mathrm{BF} & \text { bank full } & \text { LWW } & \text { left wingwall } \\ \mathrm{cfs} & \text { cubic feet per second } & \text { MC } & \text { main channel } \\ \mathrm{D}_{50} & \text { median diameter of bed material } & \text { RAB } & \text { right abutment } \\ \mathrm{DS} & \text { downstream } & \text { RABUT } & \text { face of right abutment } \\ \mathrm{elev} & \text { elevation } & \text { RB } & \text { right bank } \\ \mathrm{f} / \mathrm{p} & \text { flood plain } & \text { ROB } & \text { right overbank } \\ \mathrm{ft}^{2} & \text { square feet } & \text { RWW } & \text { right wingwall } \\ \mathrm{ft} / \mathrm{ft} & \text { feet per foot } & \text { TH } & \text { town highway } \\ \mathrm{JCT} & \text { junction } & \text { UB } & \text { under bridge } \\ \mathrm{LAB} & \text { left abutment } & \text { US } & \text { upstream } \\ \mathrm{LABUT} & \text { face of left abutment } & \text { USGS } & \text { United States Geological Survey } \\ \mathrm{LB} & \text { left bank } & \text { VTAOT Vermont Agency of Transportation } \\ \mathrm{LOB} & \text { left overbank } & \text { WSPRO } & \text { water-surface profile model }\end{array}$

In this report, the words "right" and "left" refer to directions that would be reported by an observer facing downstream. Sea level: In this report, "sea level" refers to the National Geodetic Vertical Datum of 1929-- a geodetic datum derived from a general adjustment of the first-order level nets of the United States and Canada, formerly called Sea Level Datum of 1929.

In the appendices, the above abbreviations may be combined. For example, USLB would represent upstream left bank. 


\title{
LEVEL II SCOUR ANALYSIS FOR BRIDGE 4 (ARLITH00010004) ON TOWN HIGHWAY 1, CROSSING WARM BROOK, ARLINGTON, VERMONT
}

\author{
By Scott A. Olson and Michael A. Ivanoff
}

\section{INTRODUCTION AND SUMMARY OF RESULTS}

This report provides the results of a detailed Level II analysis of scour potential at structure ARLITH00010004 on Town Highway 1 crossing Warm Brook, Arlington, Vermont (figures 1-8). A Level II study is a basic engineering analysis of the site, including a quantitative analysis of stream stability and scour (U.S. Department of Transportation, 1993). Results of a Level I scour investigation also are included in Appendix E of this report. A Level I investigation provides a qualitative geomorphic characterization of the study site. Information on the bridge, gleaned from Vermont Agency of Transportation (VTAOT) files, was compiled prior to conducting Level I and Level II analyses and is found in Appendix D.

The site is in the Taconic section of the New England physiographic province in southwestern Vermont. The $12.1-\mathrm{mi}^{2}$ drainage area consists of a predominantly rural and forested basin. In the vicinity of the study site, the surface cover is brush except for the upstream and downstream right banks which are covered by brush and grass.

In the study area, Warm Brook has an incised, straight channel with a slope of approximately $0.003 \mathrm{ft} / \mathrm{ft}$, an average channel top width of $19 \mathrm{ft}$ and an average bank height of $1 \mathrm{ft}$. The channel bed material ranges from sand to cobble with a median grain size $\left(\mathrm{D}_{50}\right)$ of $33.3 \mathrm{~mm}(0.109 \mathrm{ft})$. The geomorphic assessment at the time of the Level I and Level II site visit on July 30, 1996, indicated that the reach was stable.

The Town Highway 1 crossing of Warm Brook is a 49-ft-long, two-lane bridge consisting of one 44-foot steel-beam span (Vermont Agency of Transportation, written

communication, January 30, 1996). The bridge is supported by vertical, concrete abutments with wingwalls. The abutments have been placed on top of the previous stone abutments.

The channel is skewed approximately 0 degrees to the opening while the opening-skew-toroadway is 20 degrees.

A scour hole approximately $1.0 \mathrm{ft}$ deeper than the mean thalweg depth was observed midchannel in the upstream reach within $30 \mathrm{ft}$ of the bridge. The only scour protection measure at the site was type-2 stone fill (less than 36 inches diameter) along the upstream left bank approach to the bridge. Additional details describing conditions at the site are included in the Level II Summary and Appendices D and E. 
Scour depths and rock rip-rap sizes were computed using the general guidelines described in Hydraulic Engineering Circular 18 (Richardson and others, 1995). Total scour at a highway crossing is comprised of three components: 1) long-term streambed degradation; 2) contraction scour (due to accelerated flow caused by a reduction in flow area at a bridge) and; 3) local scour (caused by accelerated flow around piers and abutments). Total scour is the sum of the three components. Equations are available to compute depths for contraction and local scour and a summary of the results of these computations follows.

Contraction scour for all modelled flows ranged from 0.0 to $1.7 \mathrm{ft}$. The worst-case contraction scour occurred at the 500-year discharge. Abutment scour ranged from 8.3 to $11.9 \mathrm{ft}$. The worst-case abutment scour also occurred at the 500-year discharge. Additional information on scour depths and depths to armoring are included in the section titled "Scour Results". Scoured-streambed elevations, based on the calculated scour depths, are presented in tables 1 and 2. A cross-section of the scour computed at the bridge is presented in figure 8. Scour depths were calculated assuming an infinite depth of erosive material and a homogeneous particle-size distribution.

It is generally accepted that the Froehlich equation (abutment scour) gives "excessively conservative estimates of scour depths" (Richardson and others, 1995, p. 47). Usually, computed scour depths are evaluated in combination with other information including (but not limited to) historical performance during flood events, the geomorphic stability assessment, existing scour protection measures, and the results of the hydraulic analyses. Therefore, scour depths adopted by VTAOT may differ from the computed values documented herein. 


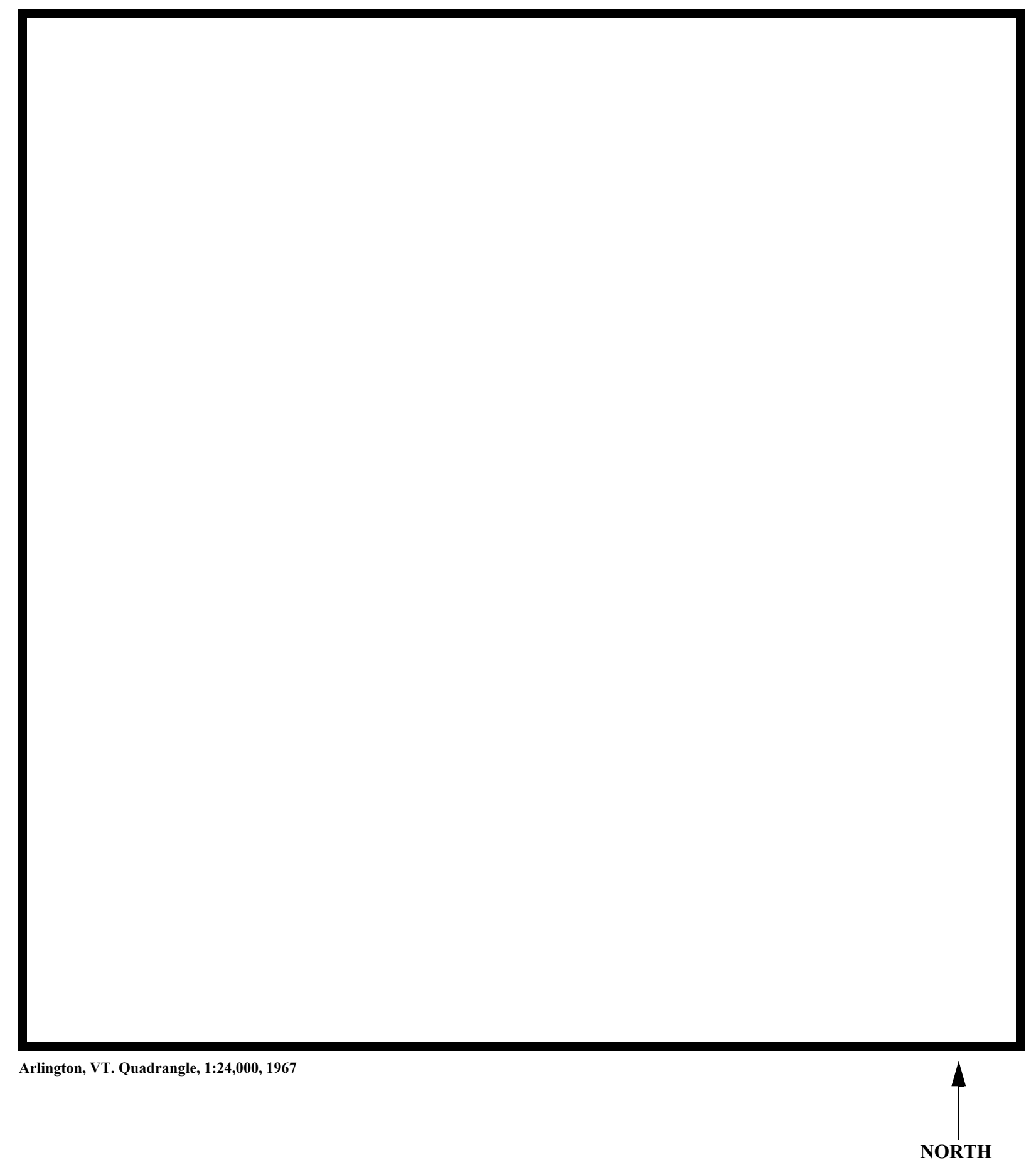

Figure 1. Location of study area on USGS 1:24,000 scale map. 
Figure 2. Location of study area on Vermont Agency of Transportation town highway map. 

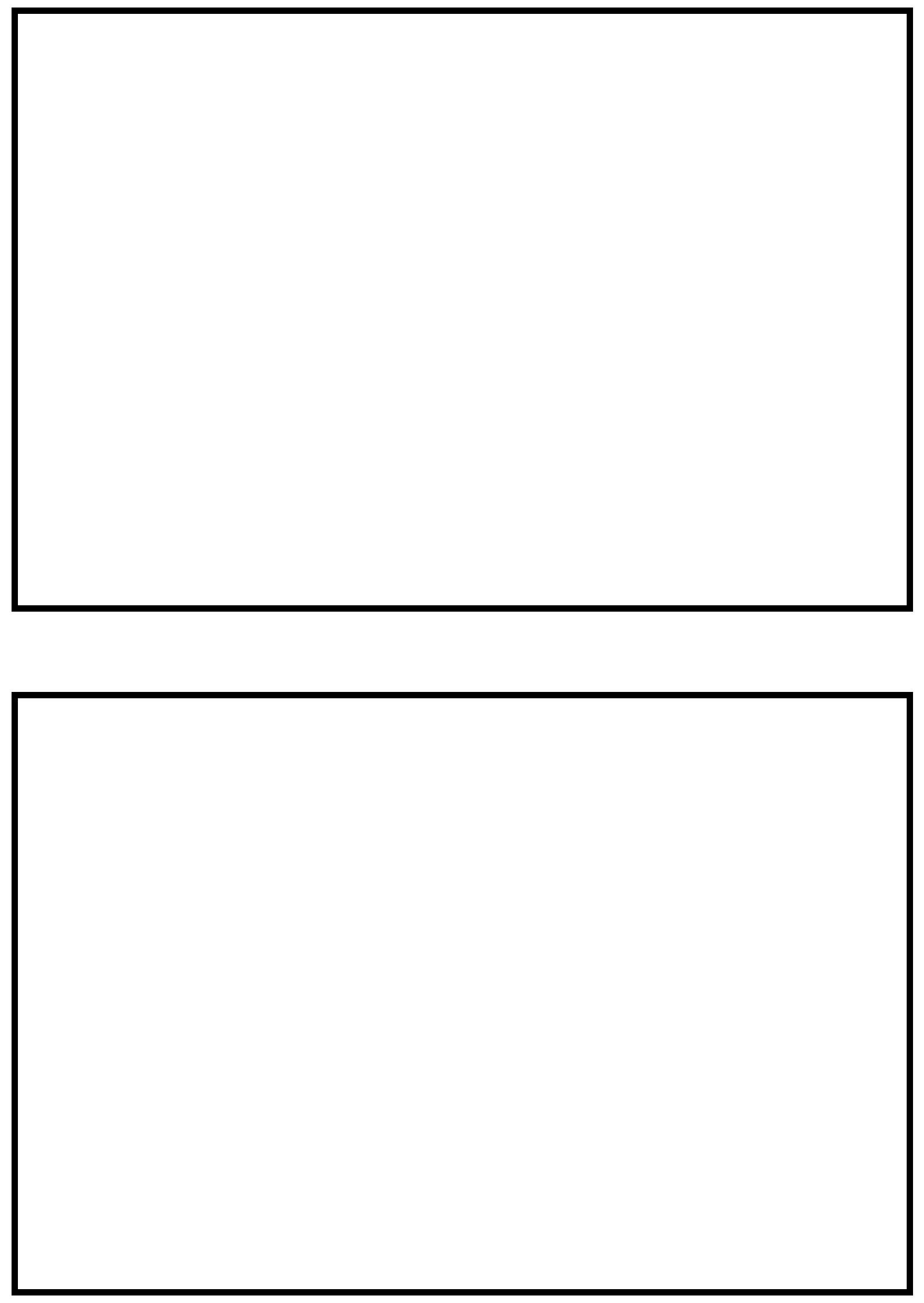

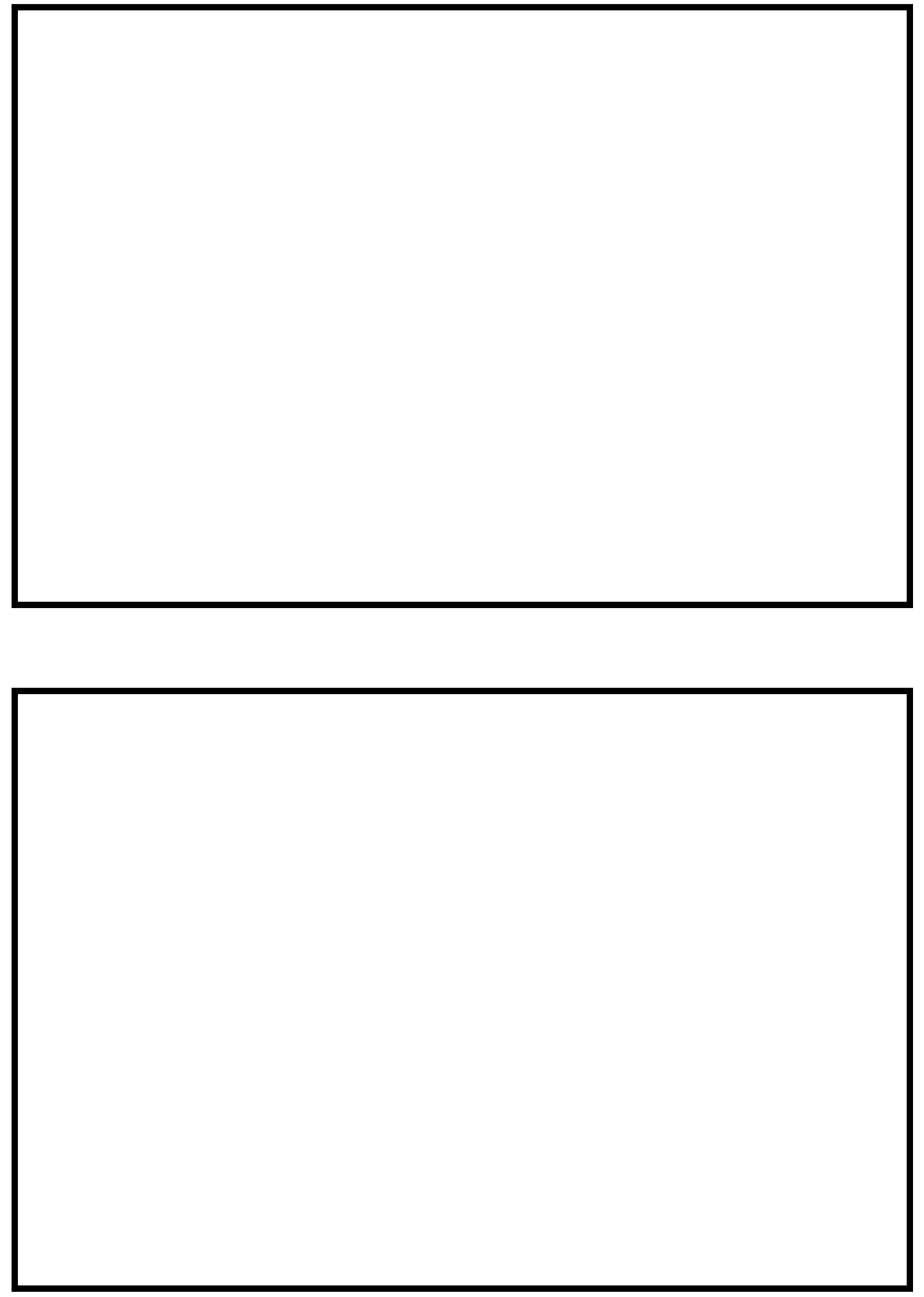


\section{LEVEL II SUMMARY}

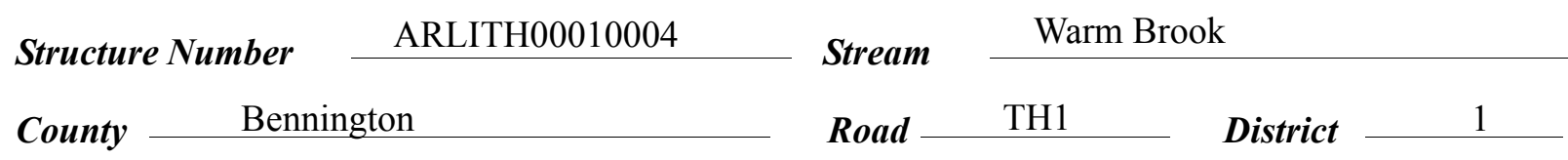

\section{Description of Bridge}

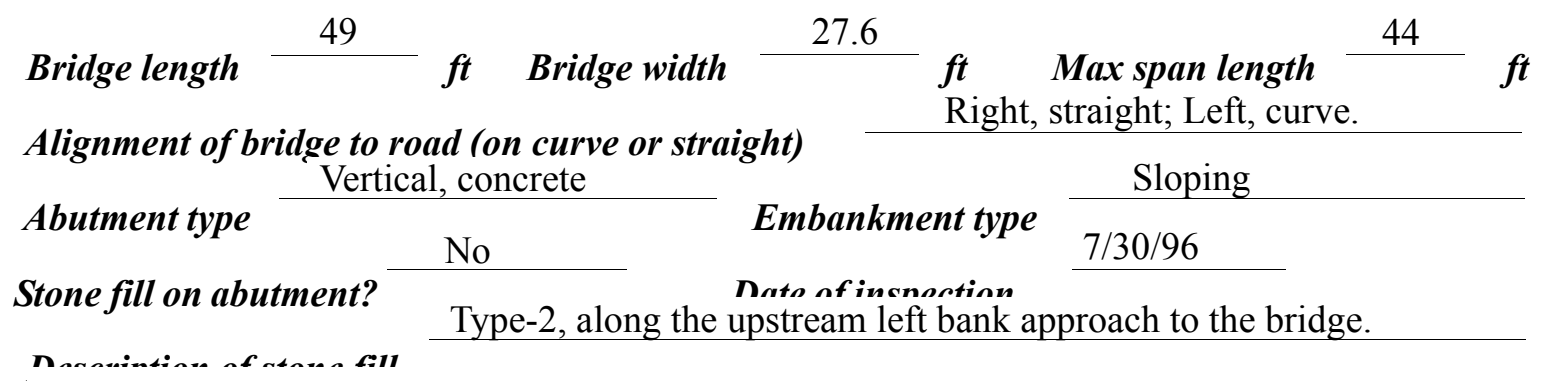

Abutments and wingwalls are concrete. The abutments

sit on the previous stone abutments.

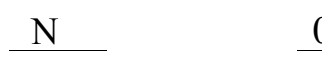

Is bridge skewed to flood flow according to Y r survey? Angle

There is a mild_channel bend through the reach.

Debris accumulation on bridge at time of Level I or Level II site visit:

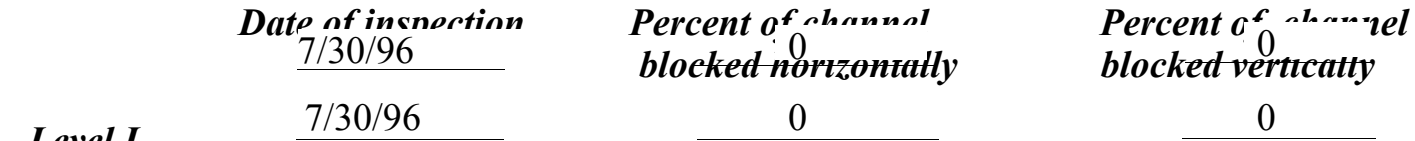

Level II Moderate. There is a beaver dam upstream of the bridge.

\section{Potential for debris}

July 30,1996 . The beaver dam upstream may affect flow. There is a dam approximately $700 \mathrm{ft}$

Doscriho anv, foaturos noar ar at tho hridoo that mav' affort flou, (includo ahsorvation dato) downstream of the bridge as well as a comparable sized tributary approximately $500 \mathrm{ft}$ downstream

of the bridge. 


\section{Description of the Geomorphic Setting}

General topography The channel is located within an approximately 1000 foot-wide, flat to slightly irregular valley with moderate relief on either side.

Geomorphic conditions at bridge site: downstream (DS), upstream (US)

Date of inspection $\quad$ 7/30/96

DS left: $\quad$ Moderately sloped overbank with road embankment.

DS right: $\quad$ Flood plain.

US left: $\quad$ Swamp.

US right: $\quad$ Flood plain.

\section{Description of the Channel}

\begin{tabular}{|c|c|c|c|}
\hline \multirow[b]{2}{*}{ Average top width } & 19 & \multirow[b]{2}{*}{ Average depth } & \multirow[b]{2}{*}{ Sand \& Gravel } \\
\hline & Gravel ${ }^{\boldsymbol{f t}}$ & & \\
\hline Predominant bed me & & Bank material & Straight, alluvial, and \\
\hline
\end{tabular}

probably incised. The upstream left overbank is swampy.

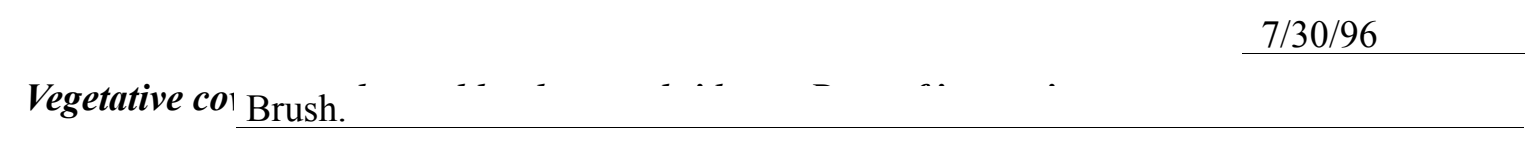

DS left: $\quad$ Brush and grass.

DS right: Brush.

US left: $\quad$ Grass.

US right: $\quad \underline{\mathrm{Y}}$

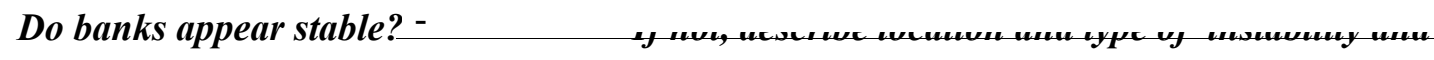

date oj observation.

July 30, 1996. The

abutments to a previous structure are located under the bridge. The old abutments significantly Describe any obstructions in channel and date of observation.

restrict flow (see Figure 8). 


\section{Hydrology}

Drainage area $\frac{12.1}{\boldsymbol{m i}^{2}}$

Percentage of drainage area in physiographic provinces: (approximate)

Physiographic province/section New England/Taconic
Percent of drainage area 100

Is drainage area considered rural or urban? — Rural _ Describe any significant urbanization:

Is there a USGS gage on the stream of interest?

No

USGS gage description

USGS gage number

Gage drainage area $\mathrm{mi}^{2}$

Is there a lake/p

\section{Calculated Discharges $\quad \underline{2,730}$ \\ 2,020 $f t^{3} / s$ \\ Q500 $\quad \mathrm{ft}^{3} / \mathrm{s}$}

The 100- and 500-year discharges were taken from

the Flood Insurance Study for the Town of Arlington (Federal Emergency Management Agency, 1986). The discharges were within a range defined by flood frequency curves determined from several empirical methods (Benson, 1962; Johnson and Tasker, 1974; FHWA, 1983; Potter, 1957a\&b; Talbot, 1887) 


\section{Description of the Water-Surface Profile Model (WSPRO) Analysis}

Datum for WSPRO analysis (USGS survey, sea level, VTAOT plans)

USGS survey

Datum tie between USGS survey and VTAOT plans

Add $223.31 \mathrm{ft}$. to the arbitrary

USGS survey datum to obtain sea level.

Description of reference marks used to determine USGS datum. $\quad$ RM1 is a chiseled X on

top of the downstream end of the right abutment (elev. $498.26 \mathrm{ft}$, arbitrary survey datum). RM2

is a bronze USGS tablet set in the downstream sidewalk at the left end of the bridge (elev.

$500.10 \mathrm{ft}$, arbitrary survey datum).

\section{Cross-Sections Used in WSPRO Analysis}

\begin{tabular}{|c|c|c|c|}
\hline${ }^{1}$ Cross-section & $\begin{array}{c}\text { Section } \\
\text { Reference } \\
\text { Distance } \\
\text { (SRD) in feet }\end{array}$ & $\begin{array}{l}{ }^{2} \text { Cross-section } \\
\text { development }\end{array}$ & Comments \\
\hline USDAM & -500 & 2 & $\begin{array}{l}\text { Section between conflu- } \\
\text { ence with Fayville Branch } \\
\text { and DS dam. The section } \\
\text { matches a section from the } \\
\text { flood insurance study } \\
\text { model (templated from } \\
\text { EXITX) }\end{array}$ \\
\hline XSEC 1 & -300 & 2 & $\begin{array}{l}\text { Section upstream of the } \\
\text { confluence with Fayville } \\
\text { Branch (templated from } \\
\text { EXITX) }\end{array}$ \\
\hline EXITX & -41 & 1 & $\begin{array}{l}\text { Exit section (also named } \\
\text { EXTEM) }\end{array}$ \\
\hline FULLV & 0 & 2 & $\begin{array}{l}\text { Downstream Full-valley } \\
\text { section (Templated from } \\
\text { EXITX) }\end{array}$ \\
\hline BRIDG & 0 & 1 & Bridge section \\
\hline RDWAY & 15 & 1 & Road Grade section \\
\hline APPRO & 70 & 1 & Approach section \\
\hline
\end{tabular}

${ }^{1}$ For location of cross-sections see plan-view sketch included with Level I field form, Appendix E. For more detail on how cross-sections were developed see WSPRO input file. 


\section{Data and Assumptions Used in WSPRO Model}

Hydraulic analyses of the reach were done by use of the Federal Highway Administration's WSPRO step-backwater computer program (Shearman and others, 1986, and Shearman, 1990). The analyses reported herein reflect conditions existing at the site at the time of the study. Furthermore, in the development of the model it was necessary to assume no accumulation of debris or ice at the site. Results of the hydraulic model are presented in the Bridge Hydraulic Summary, Appendix B, and figure 7.

Channel roughness factors (Manning's " $n$ ") used in the hydraulic model were estimated using field inspections at each cross section following the general guidelines described by Arcement and Schneider (1989). Final adjustments to the values were made during the modelling of the reach. Channel " $\mathrm{n}$ " values for the reach ranged from 0.043 to 0.048 , and overbank " $n$ " values ranged from 0.040 to 0.080 .

The starting water surface elevations were taken from a rating curve developed from model output of a section between a dam and the confluence of Warm Brook and Fayville Branch downstream of this bridge for the Flood Insurance Study for the Town of Arlington (Federal Emergency Management Agency, 1986). The surveyed exit section (EXITX) was templated to a location just upstream of the confluence (XSEC1) and to the location in between the confluence and the downstream dam (USDAM) matching the rated section.

The surveyed approach section (APPRO) was located one bridge length upstream of the upstream face as recommended by Shearman and others (1986). This location also provides a consistent method for determining scour variables. 


\section{Bridge Hydraulics Summary}

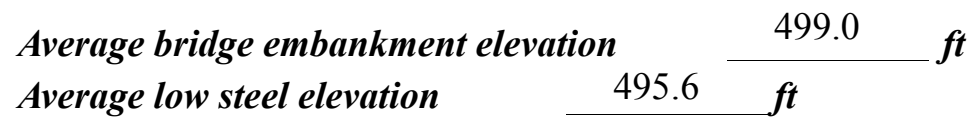

100-year discharge $\quad 2,020 \quad \mathrm{ft}^{3} / \mathrm{s}$

Water-surface elevation in bridge opening $\quad 496.2 \quad f t$

Road overtopping? ___ Y Discharge over road _ $\quad 929,3 / \mathbf{s}$

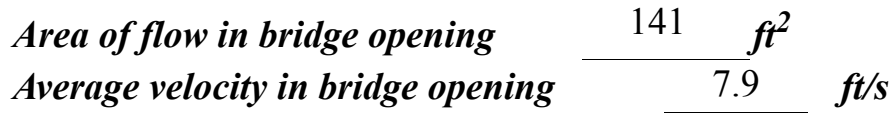

$\begin{array}{lll}\text { Maximum WSPRO tube velocity at bridge } & 10.7 \mathrm{ft} / \mathrm{s}\end{array}$

Water-surface elevation at Approach section with bridge 498.0

Water-surface elevation at Approach section without bridge $\quad 495.5$

Amount of backwater caused by bridge $\quad 2.5$ it

500-year discharge $\quad 2,730 \quad \mathrm{ft}^{3} / \mathrm{s}$

Water-surface elevation in bridge opening $\quad 495.9$ ft

Road overtopping? ___ Y Discharge over road __ $1,420 \% / \mathrm{s}$

\begin{tabular}{llll} 
Area of flow in bridge opening & 140 & $\boldsymbol{f t}^{2}$ & \\
\cline { 2 - 4 } Average velocity in bridge opening & & $9.6 \quad \mathrm{ft} / \mathrm{s}$
\end{tabular}

Maximum WSPRO tube velocity at bridge 13.0 's

Water-surface elevation at Approach section with bridge 498.3

Water-surface elevation at Approach section without bridge $\quad 496.1$

Amount of backwater caused by bridge 2.2 .

Incipient overtopping discharge $\quad 900 \quad \mathrm{ft}^{3} / \mathrm{s}$

Water-surface elevation in bridge opening 496.2 t

Area of flow in bridge opening $\quad 141 \quad \mathrm{ft}^{2}$

Average velocity in bridge opening $\quad 6.3 \quad \mathrm{ft} / \mathrm{s}$

Maximum WSPRO tube velocity at bridge $\quad 8.7 \quad \mathrm{ft} / \mathrm{s}$

Water-surface elevation at Approach section with bridge 496.8.

Water-surface elevation at Approach section without bridge $\quad 494.2$

Amount of backwater caused by bridge $\quad 2.6$ it 


\section{Scour Analysis Summary}

\section{Special Conditions or Assumptions Made in Scour Analysis}

Scour depths were computed using the general guidelines described in Hydraulic Engineering Circular 18 (Richardson and others, 1995). Scour depths were calculated assuming an infinite depth of erosive material and a homogeneous particle-size distribution. The results of the scour analysis are presented in tables 1 and 2 and a graph of the scour depths is presented in figure 8 .

The 100-year and the incipient road-overflow discharges resulted in unsubmerged orifice flow. The 500-year discharge resulted in submerged orifice flow. Contraction scour at bridges with orifice flow is best estimated by use of the Chang pressure-flow scour equation (oral communication, J. Sterling Jones, October 4, 1996). Therefore, contraction scour for each modeled discharge was computed by use of the Chang equation (Richardson and others, 1995, p. 145-146). The results of Laursen's clear-water contraction scour (Richardson and others, 1995, p. 32, equation 20) for all the modeled events were also computed and can be found in appendix F. The 500-year discharge model resulted in the worst contraction scour. The computed depths to streambed armoring suggest armoring will not limit the depth of contraction scour.

Abutment scour was computed by use of the Froehlich equation (Richardson and others, 1995, p. 48, equation 28). Variables for the Froehlich equation include the Froude number of the flow approaching the embankments, the length of the embankment blocking flow, and the depth of flow approaching the embankment less any roadway overtopping. 


\section{Scour Results}

100-yr discharge 500-yr discharge

Contraction scour:

(Scour depths in feet)

Main channel

Live-bed scour

Clear-water scour

Depth to armoring

Left overbank

Right overbank

Local scour:

Abutment scour

Left abutment

10.8

11.9

8.3

10.9

11.6-

8.8-

Right abutment

Pier scour

Pier 1

Pier 2

Pier 3

\section{Abutments:}

Left abutment

Right abutment

Piers:

Pier 1

Pier 2

\section{Riprap Sizing}

Incipient overtopping 100-yrdischarge 500-yrdischarge discharge

1.3

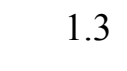

$--$
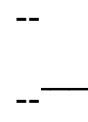
( $D_{50}$ in feet)

$1.4 \quad 0.8$

$\begin{array}{ll}1.4 & 0.8\end{array}$

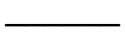

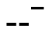

$--$

$--$

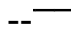




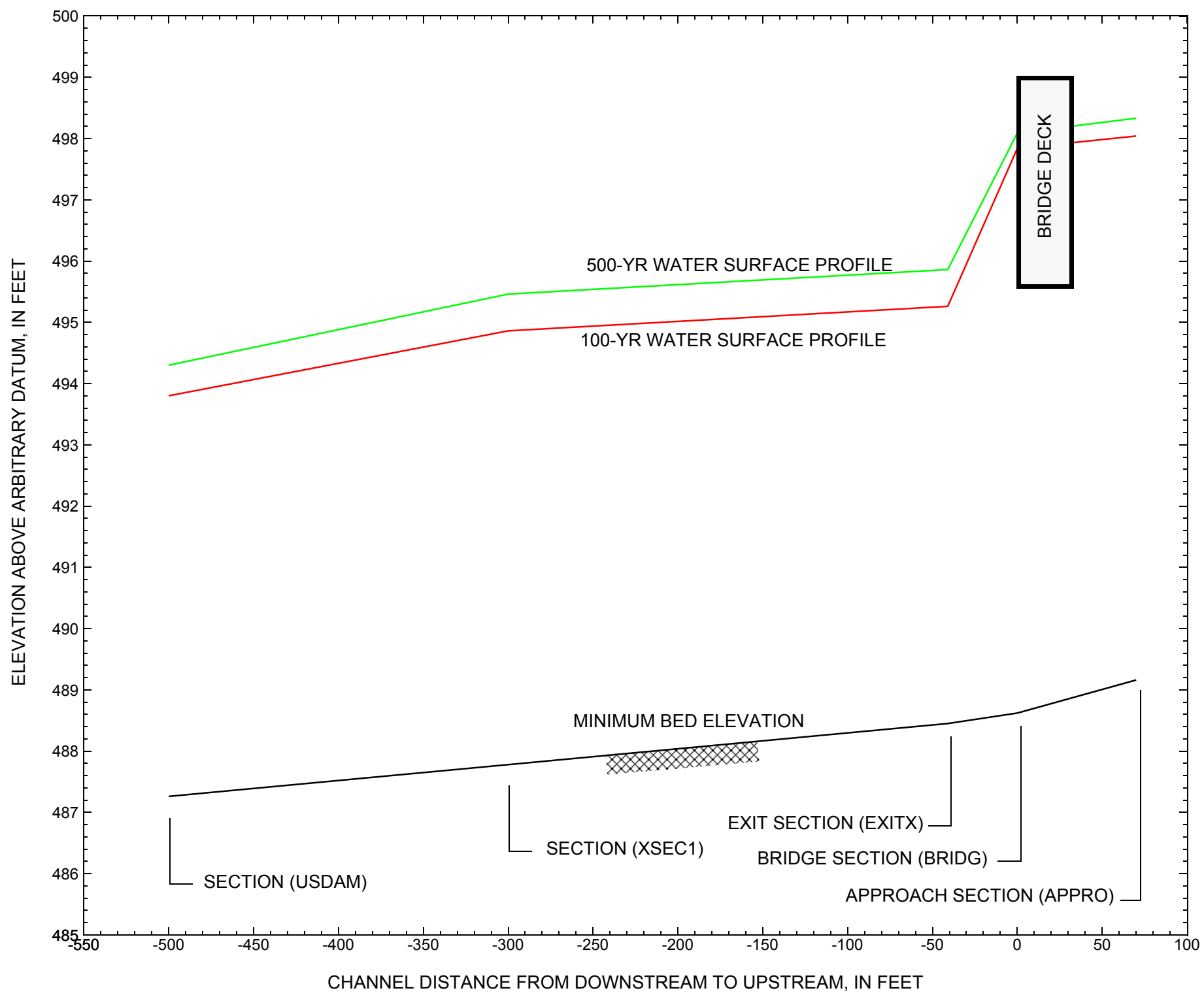

Figure 7. Water-surface profiles for the 100- and 500-yr discharges at structure ARLITH00010004 on Town Highway 1, crossing Warm Brook, Arlington, Vermont. 


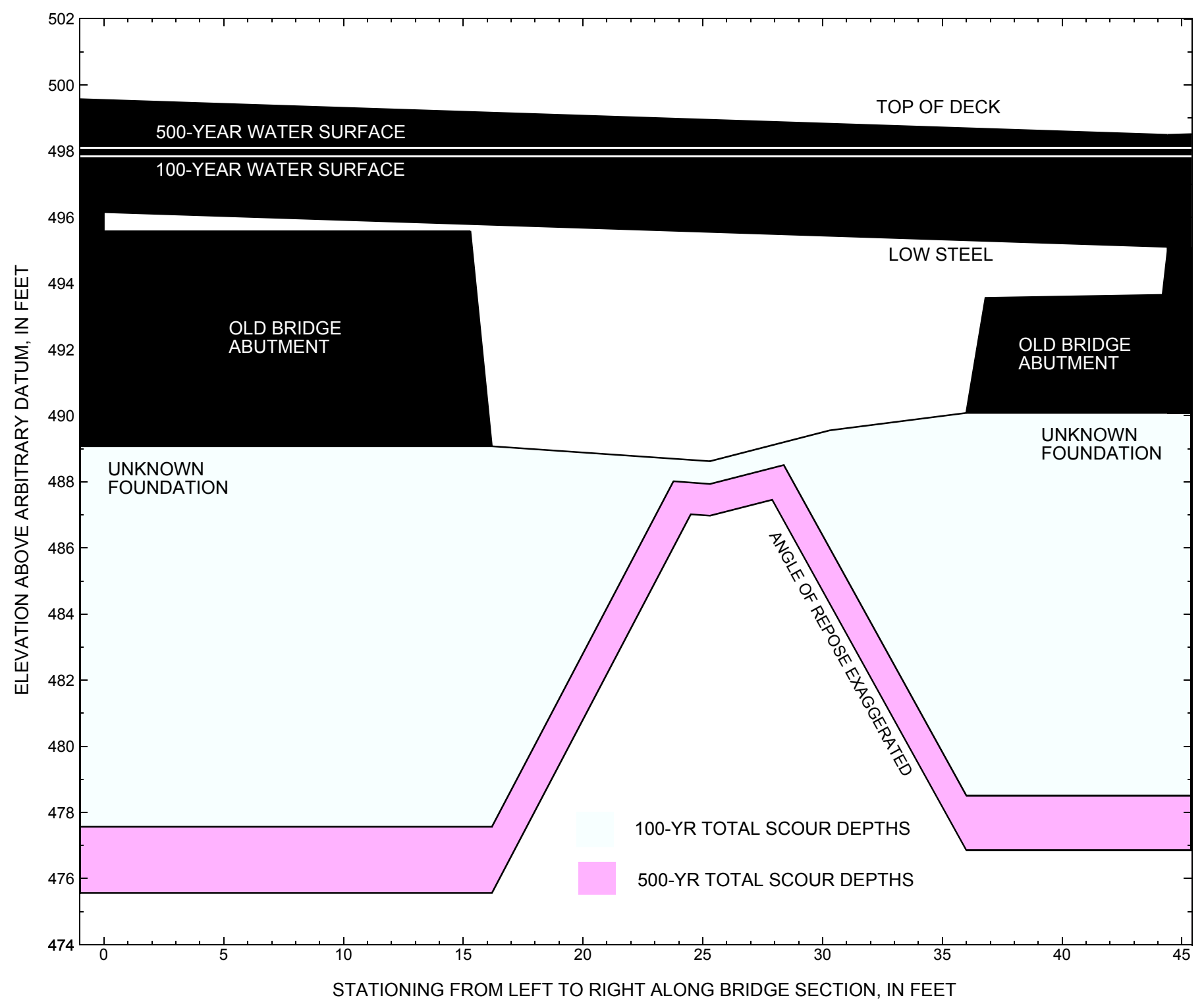

Figure 8. Scour elevations for the 100-yr and 500-yr discharges at structure ARLITH00010004 on Town Highway 1, crossing Warm Brook, Arlington, Vermont. 


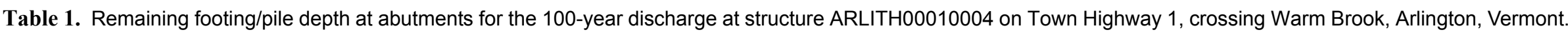
[VTAOT, Vermont Agency of Transportation; --,no data]

\begin{tabular}{|c|c|c|c|c|c|c|c|c|c|c|c|}
\hline Description & Station $^{1}$ & $\begin{array}{l}\text { VTAOT } \\
\text { minimum } \\
\text { low-chord } \\
\text { elevation } \\
\text { (feet) }\end{array}$ & $\begin{array}{l}\text { Surveyed } \\
\text { minimum } \\
\text { low-chord } \\
\text { elevation } \\
\text { (feet) }\end{array}$ & $\begin{array}{c}\text { Bottom of } \\
\text { footing } \\
\text { elevation } \\
\text { (feet) }\end{array}$ & $\begin{array}{l}\text { Channel } \\
\text { elevation at } \\
\text { abutment/ } \\
\text { pier }^{2} \\
\text { (feet) }\end{array}$ & $\begin{array}{l}\text { Contraction } \\
\text { scour depth } \\
\text { (feet) }\end{array}$ & $\begin{array}{l}\text { Abutment } \\
\text { scour } \\
\text { depth } \\
\text { (feet) }\end{array}$ & $\begin{array}{l}\text { Pier } \\
\text { scour } \\
\text { depth } \\
\text { (feet) }\end{array}$ & $\begin{array}{l}\text { Depth of } \\
\text { total scour } \\
\text { (feet) }\end{array}$ & $\begin{array}{c}\text { Elevation of } \\
\text { scour }^{2} \\
\text { (feet) }\end{array}$ & $\begin{array}{c}\text { Remaining } \\
\text { footing/pile } \\
\text { depth } \\
\text { (feet) }\end{array}$ \\
\hline \multicolumn{12}{|c|}{100 -yr. discharge is 2,020 cubic-feet per second } \\
\hline Left abutment & 0.0 & -- & 496.2 & -- & 489.1 & 0.7 & 10.8 & -- & 11.5 & 477.6 & -- \\
\hline Right abutment & 44.4 & -- & 495.1 & -- & 490.1 & 0.7 & 10.9 & -- & 11.6 & 478.5 & -- \\
\hline
\end{tabular}

1.Measured along the face of the most constricting side of the bridge.

2.Arbitrary datum for this study.

Table 2. Remaining footing/pile depth at abutments for the 500-year discharge at structure ARLITH00010004 on Town Highway 1, crossing Warm Brook, Arlington, Vermont. [VTAOT, Vermont Agency of Transportation; --, no data]

\begin{tabular}{|c|c|c|c|c|c|c|c|c|c|c|c|}
\hline Description & Station $^{1}$ & $\begin{array}{l}\text { VTAOT } \\
\text { minimum } \\
\text { low-chord } \\
\text { elevation } \\
\text { (feet) }\end{array}$ & $\begin{array}{l}\text { Surveyed } \\
\text { minimum } \\
\text { low-chord } \\
\text { elevation } \\
\text { (feet) }\end{array}$ & $\begin{array}{c}\text { Bottom of } \\
\text { footing } \\
\text { elevation } \\
\text { (feet) }\end{array}$ & $\begin{array}{c}\text { Channel } \\
\text { elevation at } \\
\text { abutment/ } \\
\text { pier }^{2} \\
\text { (feet) }\end{array}$ & $\begin{array}{l}\text { Contraction } \\
\text { scour depth } \\
\text { (feet) }\end{array}$ & $\begin{array}{l}\text { Abutment } \\
\text { scour } \\
\text { depth } \\
\text { (feet) }\end{array}$ & $\begin{array}{l}\text { Pier } \\
\text { scour } \\
\text { depth } \\
\text { (feet) }\end{array}$ & $\begin{array}{l}\text { Depth of } \\
\text { total scour } \\
\text { (feet) }\end{array}$ & $\begin{array}{c}\text { Elevation of } \\
\text { scour }^{2} \\
\text { (feet) }\end{array}$ & $\begin{array}{c}\text { Remaining } \\
\text { footing/pile } \\
\text { depth } \\
\text { (feet) }\end{array}$ \\
\hline \multicolumn{12}{|c|}{500 -yr. discharge is 2,730 cubic-feet per second } \\
\hline Left abutment & 0.0 & -- & 496.2 & -- & 489.1 & 1.7 & 11.9 & -- & 13.6 & 475.5 & -- \\
\hline Right abutment & 44.4 & -- & 495.1 & -- & 490.1 & 1.7 & 11.6 & -- & 13.3 & 476.8 & -- \\
\hline
\end{tabular}

1.Measured along the face of the most constricting side of the bridge.

2.Arbitrary datum for this study. 


\section{SELECTED REFERENCES}

Arcement, G.J., Jr., and Schneider, V.R., 1989, Guide for selecting Manning's roughness coefficients for natural channels and flood plains: U.S. Geological Survey Water-Supply Paper 2339, 38 p.

Barnes, H.H., Jr., 1967, Roughness characteristics of natural channels: U.S. Geological Survey Water-Supply Paper 1849,213 p.

Benson, M. A., 1962, Factors Influencing the Occurrence of Floods in a Humid Region of Diverse Terrain: U.S. Geological Survey WaterSupply Paper 1580-B, 64 p.

Brown, S.A. and Clyde, E.S., 1989, Design of riprap revetment: Federal Highway Administration Hydraulic Engineering Circular No. 11, Publication FHWA-IP-89-016, 156 p.

Federal Highway Administration, 1983, Runoff estimates for small watersheds and development of sound design: Federal Highway Administration Report FHWA-RD-77-158

Federal Emergency Management Agency, 1986, Flood Insurance Study, Town of Arlington, Bennington County, Vermont: Washington, D.C., July 17, 1986.

Froehlich, D.C., 1989, Local scour at bridge abutments in Ports, M.A., ed., Hydraulic Engineering--Proceedings of the 1989 National Conference on Hydraulic Engineering: New York, American Society of Civil Engineers, p. 13-18.

Hayes, D.C.,1993, Site selection and collection of bridge-scour data in Delaware, Maryland, and Virginia: U.S. Geological Survey WaterResources Investigation Report 93-4017, 23 p.

Interagency Advisory Committee on Water Data, 1982, Guidelines for determining flood flow frequency: U.S. Geological Survey, Bulletin 17B of the Hydrology Subcommittee, 190 p.

Johnson, C.G. and Tasker, G.D.,1974, Progress report on flood magnitude and frequency of Vermont streams: U.S. Geological Survey OpenFile Report 74-130, 37 p.

Lagasse, P.F., Schall, J.D., Johnson, F., Richardson, E.V., Chang, F., 1995, Stream Stability at Highway Structures: Federal Highway Administration Hydraulic Engineering Circular No. 20, Publication FHWA-IP-90-014, 144 p.

Laursen, E.M., 1960, Scour at bridge crossings: Journal of the Hydraulics Division, American Society of Civil Engineers, v. 86, no. HY2, p. 39-53.

Potter, W. D., 1957a, Peak rates of runoff in the Adirondack, White Mountains, and Maine woods area, Bureau of Public Roads

Potter, W. D., 1957b, Peak rates of runoff in the New England Hill and Lowland area, Bureau of Public Roads

Richardson, E.V. and Davis, S.R., 1995, Evaluating scour at bridges: Federal Highway Administration Hydraulic Engineering Circular No. 18, Publication FHWA-IP-90-017, 204 p.

Richardson, E.V., Simons, D.B., and Julien, P.Y., 1990, Highways in the river environment: Federal Highway Administration Publication FHWA-HI-90-016.

Ritter, D.F., 1984, Process Geomorphology: W.C. Brown Co., Debuque, Iowa, 603 p.

Shearman, J.O., 1990, User's manual for WSPRO--a computer model for water surface profile computations: Federal Highway Administration Publication FHWA-IP-89-027, 187 p.

Shearman, J.O., Kirby, W.H., Schneider, V.R., and Flippo, H.N., 1986, Bridge waterways analysis model; research report: Federal Highway Administration Publication FHWA-RD-86-108, 112 p.

Talbot, A.N., 1887, The determination of water-way for bridges and culverts.

U.S. Department of Transportation, 1993, Stream stability and scour at highway bridges, Participant Workbook: Federal Highway Administration Publication FHWA HI-91-011.

U.S. Geological Survey, 1967, Arlington, Vermont 7.5 Minute Series quadrangle map: U.S. Geological Survey Topographic Maps, Scale 1:24,000. 


\section{APPENDIX A: \\ WSPRO INPUT FILE}




\section{WSPRO INPUT FILE}

$\mathrm{XT}$

GR

GR

GR

GR

GR

*

XS

GT

$\mathrm{N}$

SA

*

XS

GT

$\mathrm{N}$

SA

*

Q

XS

GT

$\mathrm{N}$

SA

*

XS

GT

$\mathrm{N}$

SA

*

$\mathrm{BR}$

GR

GR

GR

$\mathrm{N}$

$\mathrm{CD}$

*

$\mathrm{XR}$

GR

GR

GR

GR

*

AS

GR

GR

GR

GR

GR

U.S. Geological Survey WSPRO Input File arli004.wsp Hydraulic analysis for structure ARLITH00010004 Date: 20-DEC-96 ARLINGTON BRIDGE \#4 OVER WARM BROOK (FAS 114) SAO

$62930 \quad 552553551516 \quad 17 \quad 13 \quad 3 * \begin{array}{llllllllll}15 & 14 & 23 & 21 & 11 & 12 & 4 & 7 & 3\end{array}$

$34004600 \quad 1510$

$493.8 \quad 494.3 \quad 492.9$

EXTEM $\quad-41$

$-157.8,504.28$

$-6.3,491.96$

$-51.8,497.02$

$6.1,492.08$

$-32.8,496.20$

$-27.3,494.22$

$20.6,488.45$

$24.7,488.48$

$15.2,491.26$

$29.7,489.07$

$31.1,490.67$

$35.9,491.80$

$505.6,499.55$

USDAM -500

$-1.19$

0.060

$15.2^{0.048}$

35.9

$\mathrm{XSEC1}$

$-300$

$-0.67$

0.060

$15.2^{0.048}$

35.9

$20202730 \quad 900$

EXITX -41

$$
0
$$

0.060

0.048

35.9

FULLV

$$
0.14
$$

0.060

$$
15.2^{0.048} \quad 35.9^{0.040}
$$

BRIDG

$0 \quad 495.62 \quad 20$

$0.0,496.15$

$25.3,488.62$

$44.2,493.65$

0.043

$135.3 * \star 753.3$

RDWAY $\quad 15 \quad 28$

$$
-383.9,514.98
$$

$-18.4,500.40$

$46.1,498.49$

$492.3,498.70$

$$
\begin{array}{rrr}
\text { APPRO } & 70 \\
-101.2, & 503.77 \\
16.2, & 489.34 \\
31.9, & 490.19 \\
53.6, & 493.39 \\
274.9, & 496.27
\end{array}
$$

$0.0,495.57$

$30.3,489.55$

$44.4,494.97$

$-300.6,511.04$

$-2.6,499.55$

$130.3,497.30$

$-173.4,505.66$

$557.1,499.58$

$-42.8,491.42$

$18.4,489.21$

$32.3,490.87$

$105.5,494.49$

$366.4,495.88$
$-2.4,500.48$

$290.2,496.81$

$576.4,500.06$

$15.3,495.56$

$36.0,490.08$

$44.4,495.10$

$-93.5, \quad 502.11$

$45.9,499.47$

$401.6,497.20$

$-11.7,491.95$

$23.0,489.16$

$32.8,491.17$

$135.2,494.65$

$460.9,497.26$
$16.2,489.07$

$36.8,493.56$

$0.0,496.15$ 
WSPRO INPUT FILE (continued)

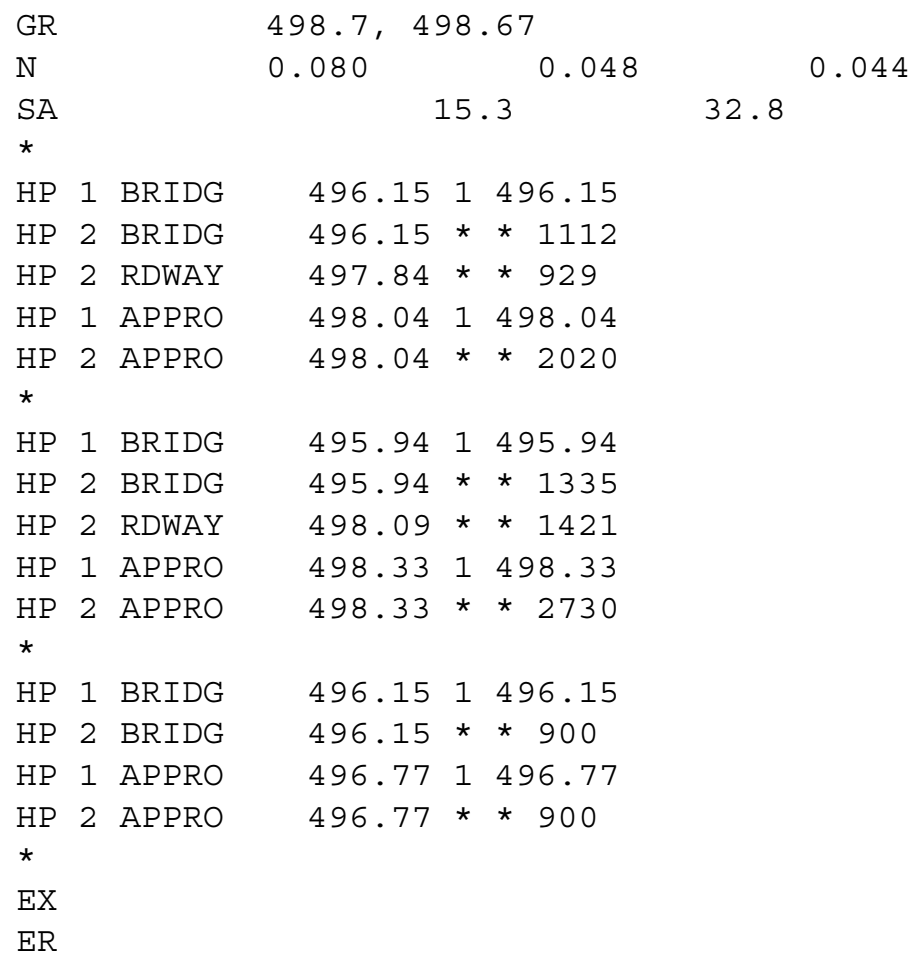




\section{APPENDIX B: \\ WSPRO OUTPUT FILE}




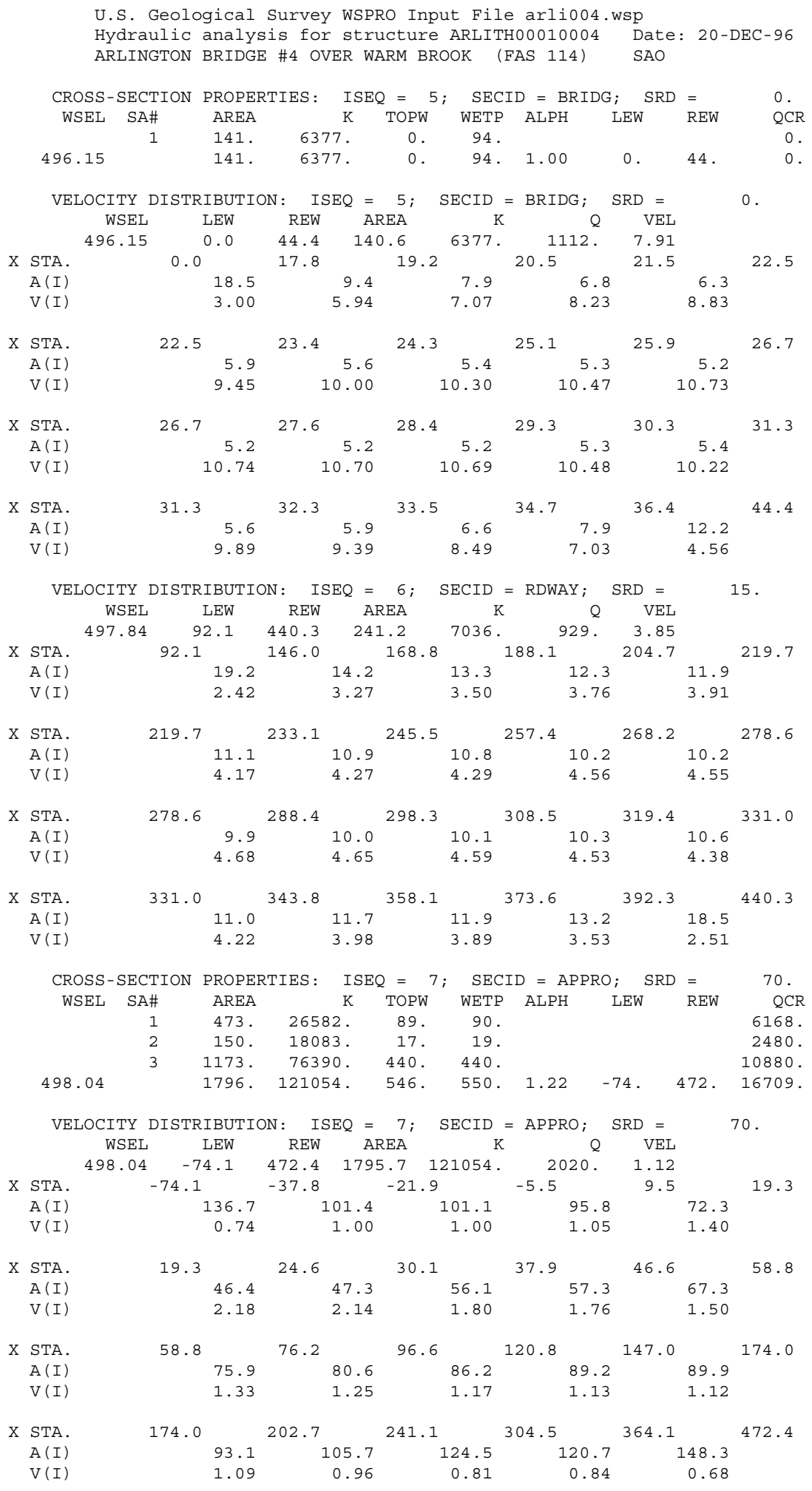


WSPRO OUTPUT FILE (continued)

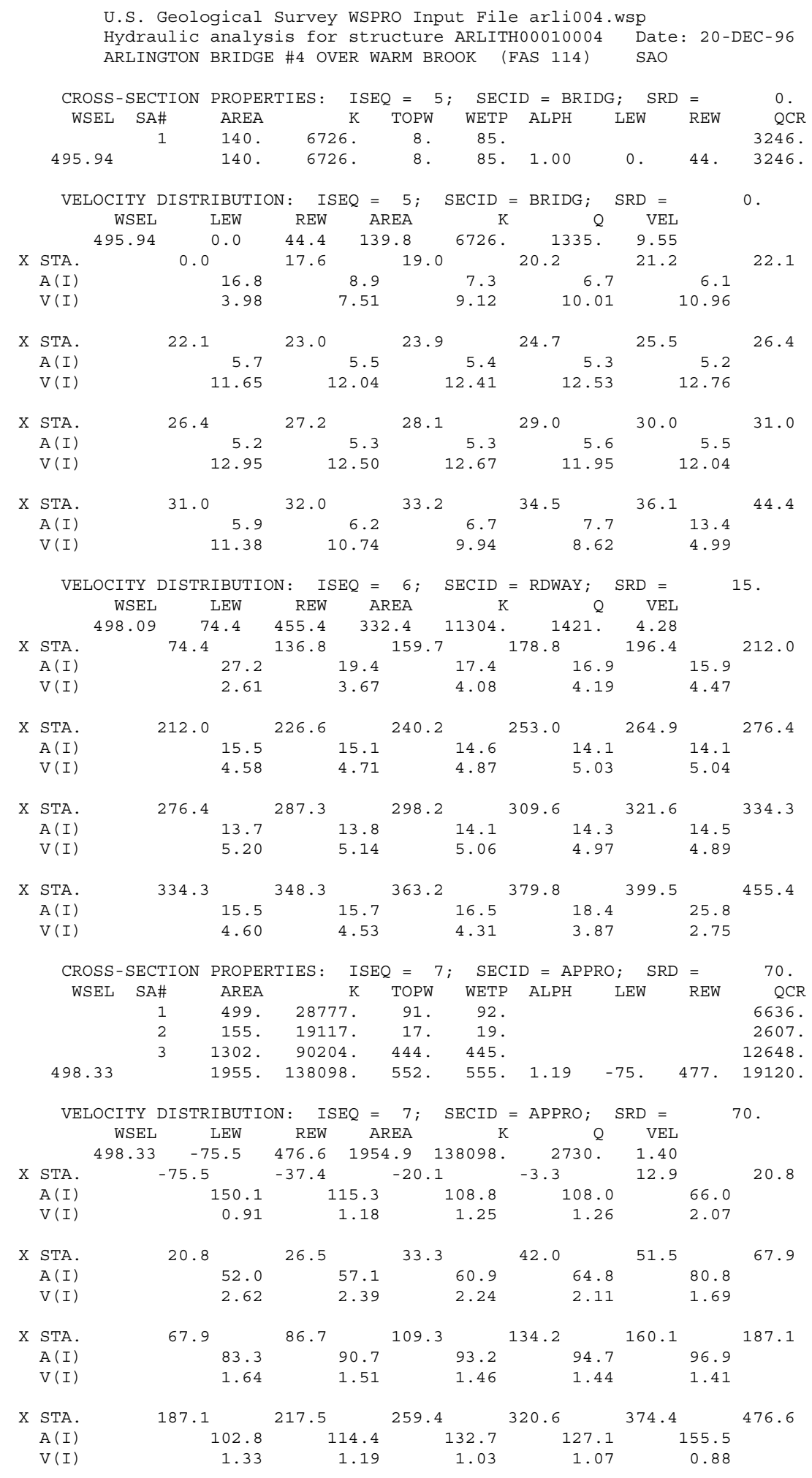


WSPRO OUTPUT FILE (continued)

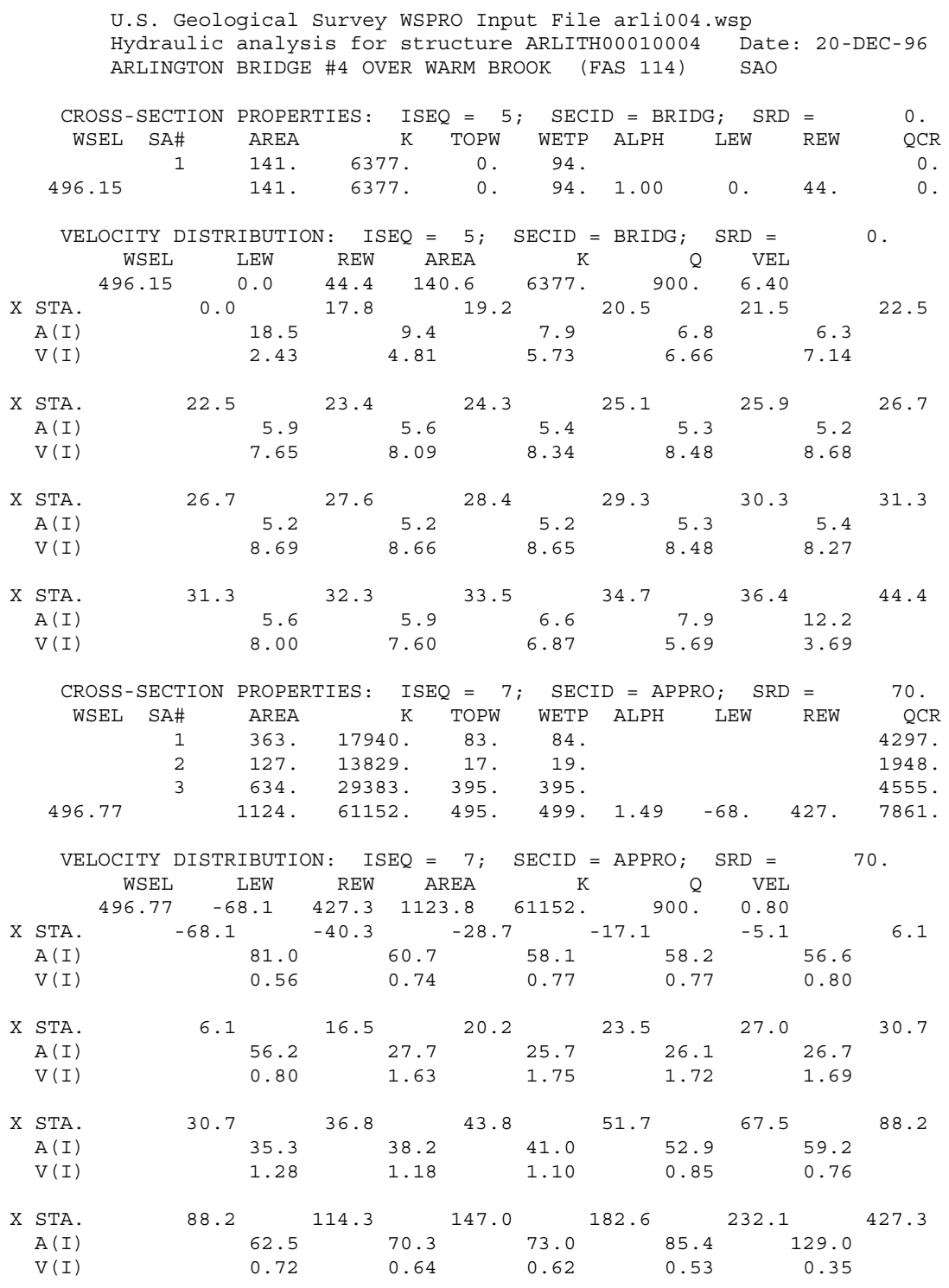


WSPRO OUTPUT FILE (continued)

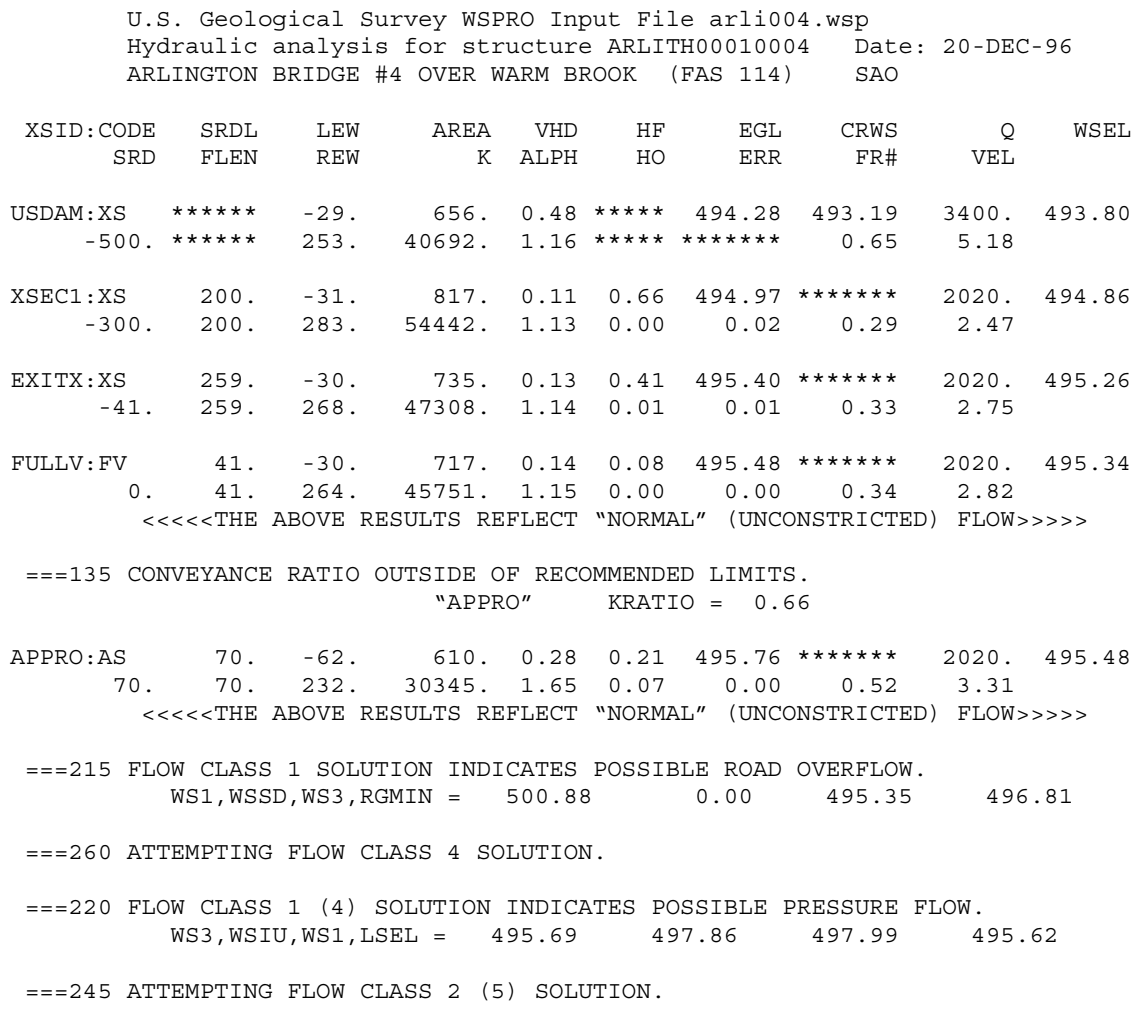


WSPRO OUTPUT FILE (continued)

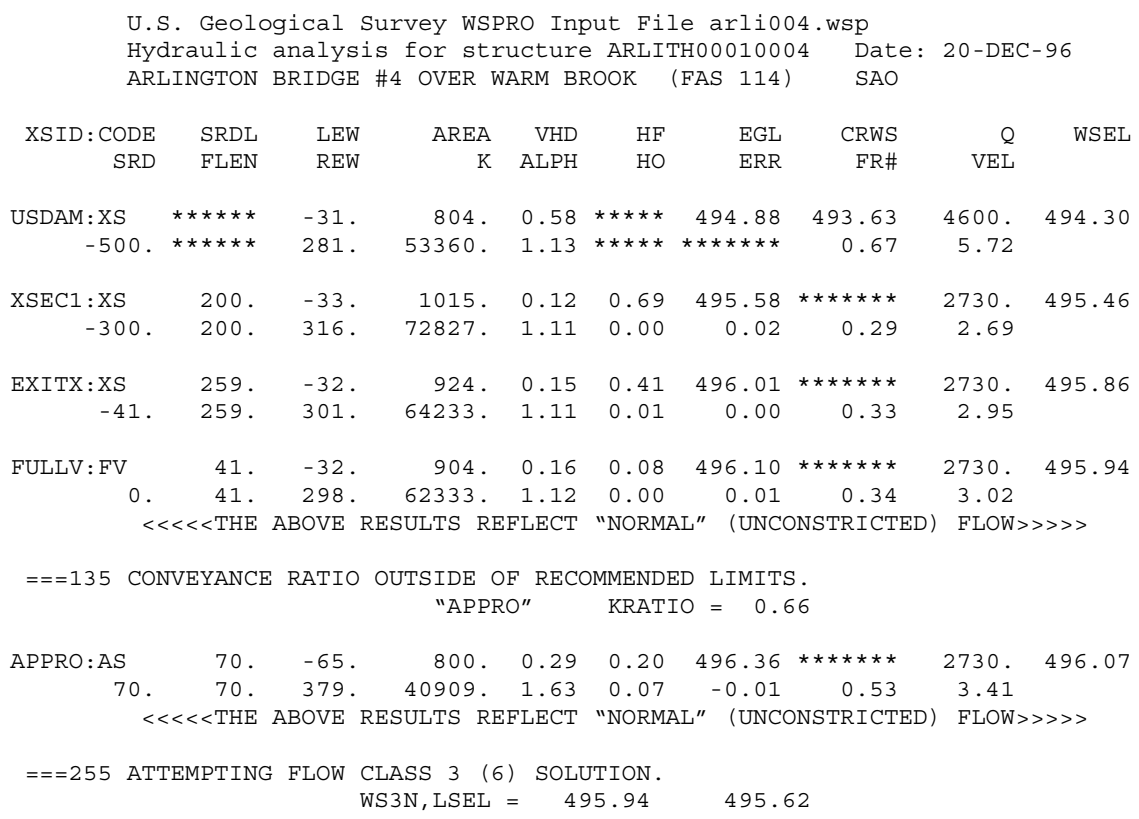


WSPRO OUTPUT FILE (continued)

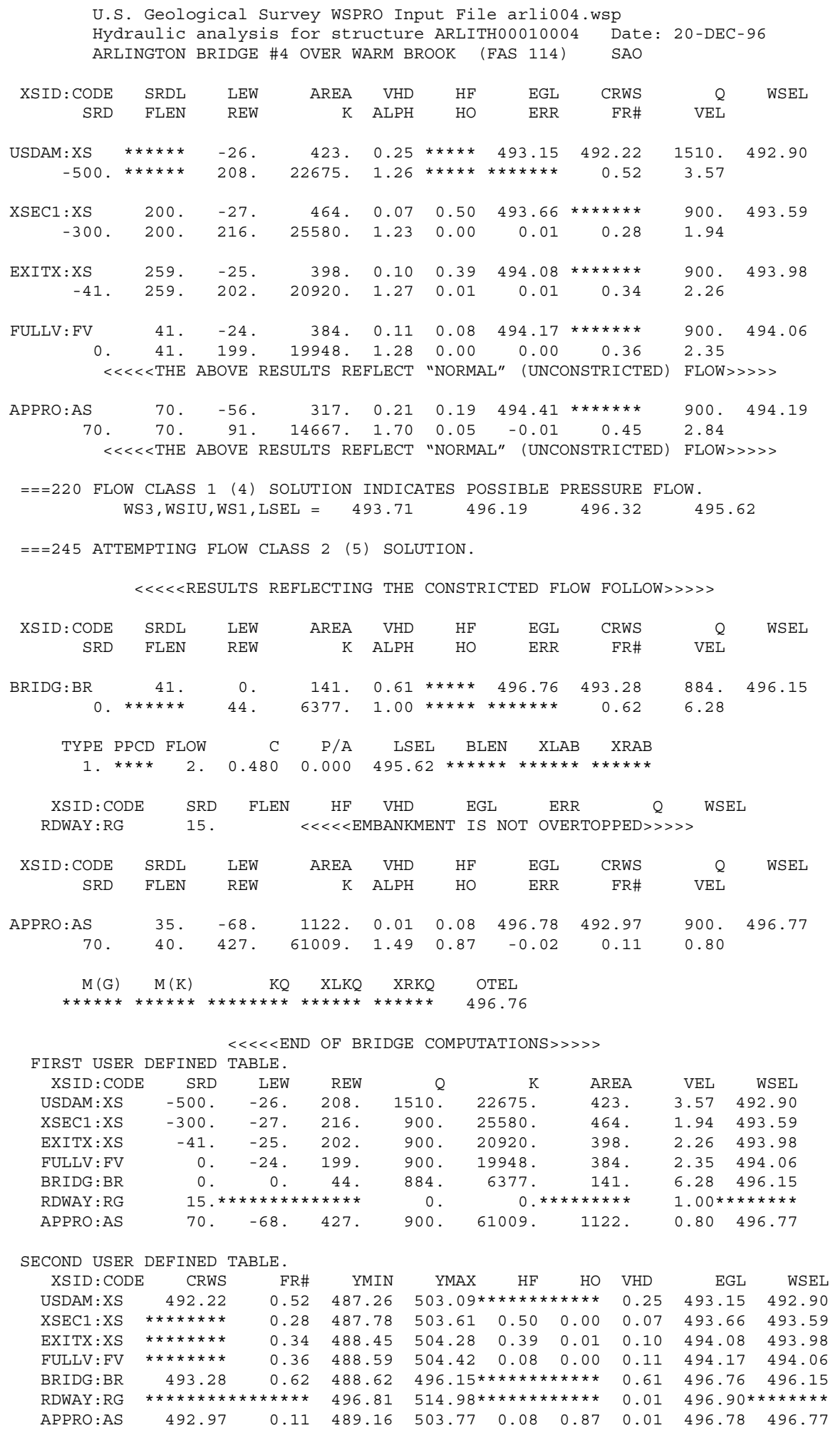




\section{APPENDIX C:}

\section{BED-MATERIAL PARTICAL-SIZE DISTRIBUTION}




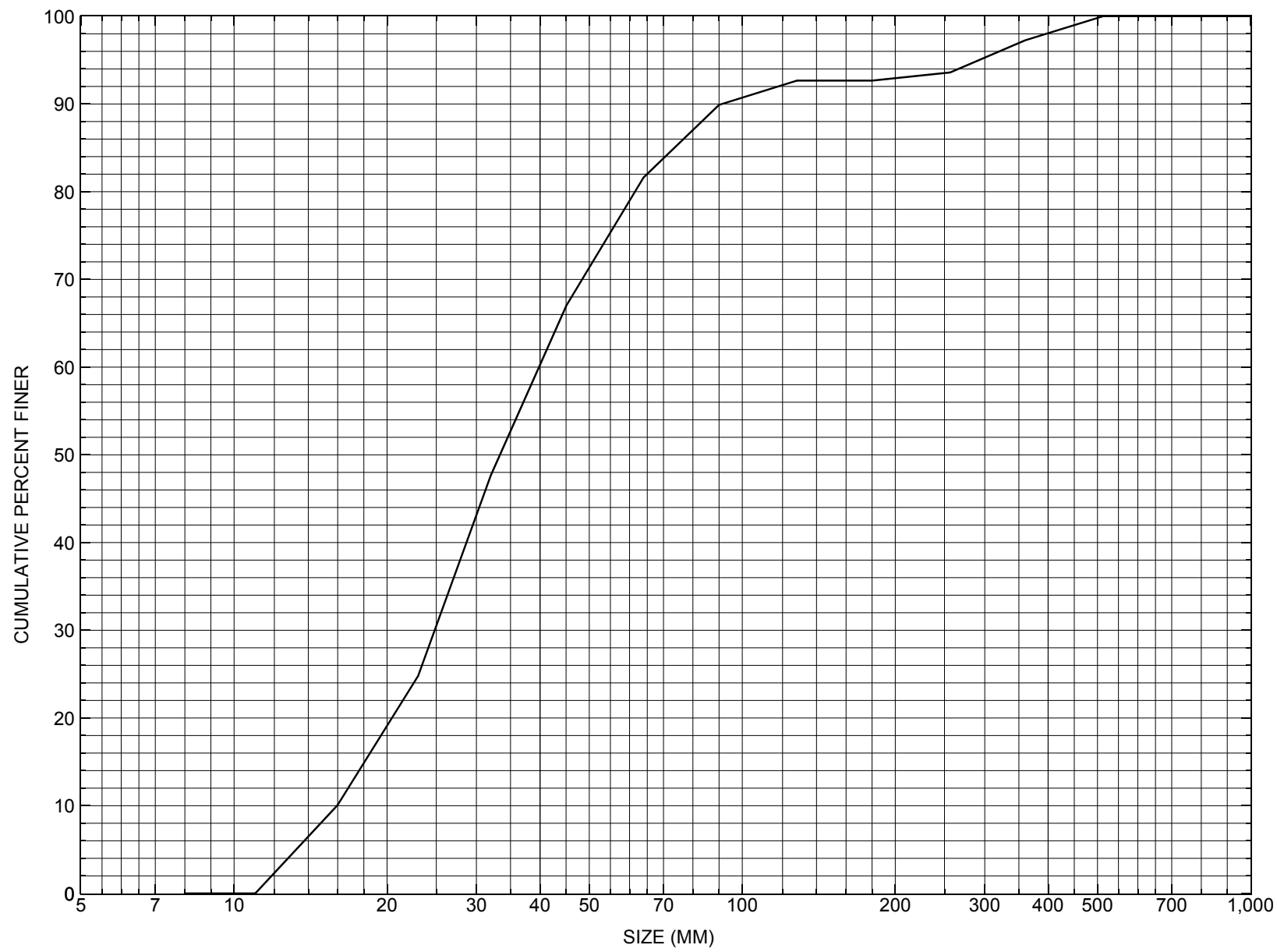

Appendix C. Bed material particle-size distribution for a pebble count in the channel approach of structure ARLITH00010004, in Arlington, Vermont. 


\section{APPENDIX D: \\ HISTORICAL DATA FORM}




\section{Structure Number ARLITH00010004}

\section{General Location Descriptive}

Data collected by (First Initial, Full last name) $\underline{\text { L. }}$. Medalie

Date $(M M / D D / Y Y) \_\mathbf{0 1} / \underline{30} / \underline{96}$

Highway District Number (I - 2; nn) 01

Town (FIPS place code; I - 4; nnnnn) $\mathbf{0 1 3 7 5}$

Waterway (I - 6) WARM BROOK

Route Number FAS 114

Topographic Map Arlington

Latitude (I - 16; nnnn.n) $\mathbf{4 3 0 3 8}$
County (FIPS county code; I - 3; nnn)

Mile marker (I - 11; nnn.nnn) $\mathbf{0 0 0 9 5 0}$

Road Name (I - 7): TR 01

Vicinity (I - 9) 0.9 MI E JCT. U.S.7 S

Hydrologic Unit Code: $\mathbf{2 0 2 0 0 0 3}$

Longitude (i - 17; nnnnn.n) $\mathbf{7 3 0 8 8}$

\section{Select Federal Inventory Codes}

FHWA Structure Number $(I$ - 8) $\mathbf{2 0 0 1 1 4 0 0 0 4 0 2 0 1}$

Maintenance responsibility $(I-21 ; n n) \quad \mathbf{0 3}$

Year built (I - 27; YYYY) 1934

Average daily traffic, ADT (I - 29; nnnnnn) $\underline{001987}$

Year of ADT (I - 30; YY) $\mathbf{9 1}$

Opening skew to Roadway $(I-34 ; n n) \quad 15$

Operational status $(I-41 ; X)$ A

Structure type (I - 43; nnn) $\mathbf{3 0 2}$

Approach span structure type (I - 44; nnn) $\mathbf{0 0 0}$

Number of spans (I - 45; nnn) $\mathbf{0 0 1}$

Number of approach spans (I - 46; nnnn) $\mathbf{0 0 0 0}$

Comments:

According to the structural inspection report dated $7 / 21 / 94$, the structure is a single span rolled beam bridge. The curtain wall at the left abutment has some minor cracking and scaling. The stem of the left abutment has some cracking with leakage at the fascia lines. The wingwalls of both abutments are in good condition with only minor cracking and scaling. The curtain wall at the right abutment has some leakage at the top and some cracking and heavy scaling at the bottom. The stem of the right abutment has some hairline vertical cracking. There has been additional fill and stone fill placed along the edge of the channel at the upstream left wingwall. The channel takes a slight turn into and out of (continued on page 34) 


\section{Bridge Hydrologic Data}

Is there hydrologic data available? $\underline{\mathbf{N}}$ if No, type ctrl-n $h \quad$ VTAOT Drainage area $\left(\mathrm{mi}^{2}\right)^{2}$ :

Terrain character:

Stream character \& type:

Streambed material:

Discharge Data (cfs):

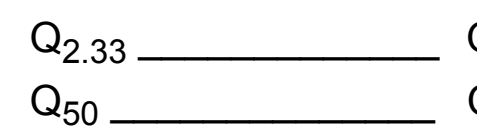

$Q_{10}$ $\mathrm{Q}_{100}$
$Q_{25}$

$Q_{500}$

Record flood date ( $M M / D D / Y Y$ ):

Estimated Discharge (cfs): Velocity at $Q$

Water surface elevation (ft):

Ice conditions (Heavy, Moderate, Light) : (ft/s):

Debris (Heavy, Moderate, Light):

The stage increases to maximum highwater elevation (Rapidly, Not rapidly):

The stream response is (Flashy, Not flashy):

Describe any significant site conditions upstream or downstream that may influence the stream's stage:

Watershed storage area (in percent): $\%$

The watershed storage area is: (1-mainly at the headwaters; 2- uniformly distributed; 3-immediatly upstream oi the site)

Water Surface Elevation Estimates for Existing Structure:

\begin{tabular}{|l|l|l|l|l|l|}
\hline $\begin{array}{l}\text { Peak discharge frequency } \\
\text { Water surface elevation (ft) } \\
\text { Velocity }(\mathrm{ft} / \mathrm{sec})\end{array}$ & $\mathrm{Q}_{2.33}$ & $\mathrm{Q}_{10}$ & $\mathrm{Q}_{25}$ & $\mathrm{Q}_{50}$ & $\mathrm{Q}_{100}$ \\
\hline
\end{tabular}

Long term stream bed changes:

Is the roadway overtopped below the $\mathrm{Q}_{100}$ ? (Yes, No, Unknown):

Frequency:

Relief Elevation (ft):

Discharge over roadway at $Q_{100}\left(f t^{3} / \mathrm{sec}\right)$ :

Are there other structures nearby? (Yes, No, Unknown): Upstream distance (miles): Town: If No or Unknown, type ctrl-n os

Highway No. : Structure No. : Year Built:

Clear span (ft): Clear Height (ft): Structure Type: Full Waterway $\left(t^{2}\right)$ : 
Downstream distance (miles): Town: Year Built:

Highway No. : Structure No. : Structure Type:

Clear span (ft): Clear Height (ft): Full Waterway $\left(t^{2}\right)$ :

Comments:

the structure. There is some minor debris in the channel. There are laid up stone retaining walls from an earlier structure left in place in front of the abutments. A memo in the inspection folder notes that a new subfooting at the east abutment was poured on 9/26/91.

\section{USGS Watershed Data}

Watershed Hydrographic Data

Drainage area $(D A) \underline{12.06} \mathrm{mi}^{2}$ Lake and pond area $\underline{\mathbf{0 . 0 8}}$ $\mathrm{mi}^{2}$

Watershed storage (ST)

Bridge site elevation $\mathbf{7 2 0}$ 0.7 Lake and pond area $\%$

Main channel length $\mathbf{6 . 5 6}$ Headwater elevation 1481 $\mathrm{ft}$ $10 \%$ channel length elevation $\mathbf{7 4 0}$ $\mathrm{ft} \quad 85 \%$ channel length elevation 930 $\mathrm{ft}$

Main channel slope $(S) \quad 21.7 \quad \mathrm{ft} / \mathrm{mi}$

Watershed Precipitation Data

Average site precipitation in Average headwater precipitation in

Maximum 2yr-24hr precipitation event $(124,2)$ in

Average seasonal snowfall (Sn) $\mathrm{ft}$ 


\section{Bridge Plan Data}

Are plans available? Y* $^{*}$ If no, type ctrl-n pl Date issued for construction (MM/YYYY):

Project Number SA\#29 Minimum channel bed elevation:

Low superstructure elevation: USLAB DSLAB USRAB DSRAB Benchmark location description:

B.M. \#7, paint spot on corner of downstream right abutment, elev. 178.07

Reference Point (MSL, Arbitrary, Other): Unknown Datum (NAD27, NAD83, Other):

Foundation Type: 4 (1-Spreadfooting; 2-Pile; 3- Gravity; 4-Unknown)

If 1: Footing Thickness ___ Footing bottom elevation:

If 2: Pile Type: (1-Wood; 2-Steel or metal; 3-Concrete) Approximate pile driven length:

If 3: Footing bottom elevation:

Is boring information available? $\mathrm{N}$ If no, type ctrl-n bi Number of borings taken:

Foundation Material Type: (1-regolith, 2-bedrock, 3-unknown)

Briefly describe material at foundation bottom elevation or around piles:

Comments:

*Not sure whether these plans correspond with Arlington Bridge 4.

According to Project No - 70 - 30 (T.H. \#1) PWA-6114 (Record Plans) 1935,

Sheet 6 shows road over unnamed brook, with the following information:

Concrete bridge S.A. \#29; constructed 1931; clear span 44'; roadway width 20'; concrete sidewalk 4' The sketch also shows a barn very close (within several feet) to the upstream right bank and roadway. 


\section{Cross-sectional Data}

Is cross-sectional data available? $\mathbf{N}$ If no, type ctrl-n xs

Source (FEMA, VTAOT, Other)?

Comments:

\begin{tabular}{|l|l|l|l|l|l|l|l|l|l|l|l|}
\hline Station & & & & & & & & & & & \\
\hline Feature & & & & & & & & & & & \\
\hline $\begin{array}{l}\text { Low cord } \\
\text { elevation }\end{array}$ & & & & & & & & & & & \\
\hline $\begin{array}{l}\text { Bed } \\
\text { elevation }\end{array}$ & & & & & & & & & & & \\
\hline $\begin{array}{l}\text { Low cord to } \\
\text { bed length }\end{array}$ & & & & & & & & & & & \\
\hline Station & & & & & & & & & & & \\
\hline Feature & & & & & & & & & & & \\
\hline $\begin{array}{l}\text { Low cord } \\
\text { elevation }\end{array}$ & & & & & & & & & & & \\
\hline $\begin{array}{l}\text { Bed } \\
\text { elevation }\end{array}$ & & & & & & & & & & & \\
\hline $\begin{array}{l}\text { Low cord to } \\
\text { bed length }\end{array}$ & & & & & & & & & & & \\
\hline
\end{tabular}

Source (FEMA, VTAOT, Other)?

Comments:

\begin{tabular}{|l|l|l|l|l|l|l|l|l|l|l|l|}
\hline Station & & & & & & & & & & & \\
\hline Feature & & & & & & & & & & & \\
\hline $\begin{array}{l}\text { Low cord } \\
\text { elevation }\end{array}$ & & & & & & & & & & & \\
\hline $\begin{array}{l}\text { Bed } \\
\text { elevation }\end{array}$ & & & & & & & & & & & \\
\hline $\begin{array}{l}\text { Low cord to } \\
\text { bed length }\end{array}$ & & & & & & & & & & & \\
\hline Station & & & & & & & & & & & \\
\hline Feature & & & & & & & & & & & \\
\hline $\begin{array}{l}\text { Low cord } \\
\text { elevation }\end{array}$ & & & & & & & & & & & \\
\hline $\begin{array}{l}\text { Bed } \\
\text { elevation }\end{array}$ & & & & & & & & & & & \\
\hline $\begin{array}{l}\text { Low cord to } \\
\text { bed length }\end{array}$ & & & & & & & & & & & \\
\hline
\end{tabular}




\section{APPENDIX E: \\ LEVEL I DATA FORM}


U. S. Geological Survey

Bridge Field Data Collection and Processing Form

Qa/Qc Check by: $\underline{\text { EW Date: } 10 / 1 / 96}$

\section{Structure Number}

ARLITH00010004

\section{A. General Location Descriptive}

1. Data collected by (First Initial, Full last name) M. IVANOFF

2. Highway District Number 01

Mile marker $\mathbf{0 0 0 9 5 0}$

County BENNINGTON 003

Town ARLINGTON 01375

Waterway (I - 6) WARM BROOK

Road Name TR1

Route Number FAS114

Hydrologic Unit Code: 2020003

3. Descriptive comments:

LOCATED 0.9 MILES EAST OF JUNCTION WITH US 7 SOUTH.

\section{B. Bridge Deck Observations}
4. Surface cover... LBUS 5
RBUS 4
LBDS 5
RBDS 5
Overall 5

(2b us, ds,lb,rb: 1- Urban; 2- Suburban; 3- Row crops; 4- Pasture; 5- Shrub- and brushland; 6- Forest; 7- Wetland)
5. Ambient water surface... US 1
UB 1
DS 1
(1- pool; 2- riffle)

6. Bridge structure type 1 (1- single span; 2- multiple span; 3- single arch; 4- multiple arch; 5-cylindrical culvert; 6- box culvert; or 7- other)
7. Bridge length 49
(feet)
Span length $\underline{44}$
(feet)
Bridge width 27.6 (feet)

\section{Road approach to bridge:}
8. LB 2 RB 1
( 0 even, 1- lower, 2- higher)
9. LB 1
RB 1
(1- Paved, 2- Not paved)

10. Embankment slope (run / rise in feet / foot)

US left

US right

\begin{tabular}{|c|c|c|c|}
\hline \multicolumn{2}{|c|}{ Protection } & \multirow{2}{*}{ 13.Erosion } & 14.Severity \\
\hline 11.Type & 12.Cond. & $\mathbf{0}$ & - \\
\hline $\mathbf{0}$ & - & $\mathbf{0}$ & - \\
\hline $\mathbf{0}$ & - & $\mathbf{0}$ & - \\
\hline $\mathbf{0}$ & - & $\mathbf{2}$ & $\mathbf{1}$ \\
\hline $\mathbf{0}$ & - & $\mathbf{0}$ & - \\
\hline
\end{tabular}

Bank protection types: 0- none; 1- < 12 inches;

2- < 36 inches; 3- < 48 inches;

4- < 60 inches; 5- wall / artificial levee

Bank protection conditions: 1- good; 2- slumped;

3- eroded; 4- failed

Erosion: 0 - none; 1- channel erosion; 2-

road wash; 3- both; 4- other

Erosion Severity: 0 - none; 1- slight; 2- moderate; 3- severe

\section{Channel approach to bridge (BF):}

15. Angle of approach: $\mathbf{1 0}$

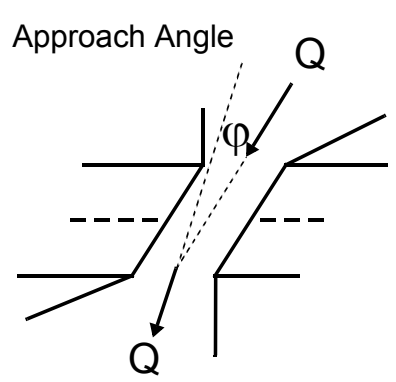

17. Channel impact zone 1:

Where? LB (LB, RB)

Range? 15 feet $\mathbf{U B}$

Channel impact zone 2:

Where? (LB, RB)

Range? feet (US, UB, DS) to feet

16. Bridge skew: $\mathbf{0}$ Bridge Skew Angle

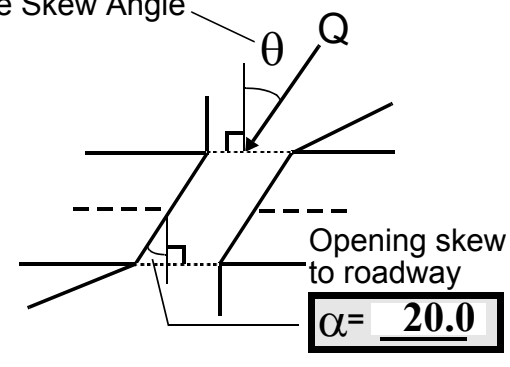

\section{Exist? $\mathbf{Y}(Y$ or $N)$}

Severity 1

$U B, D S)$ to $\underline{60}$ feet $\underline{\text { DS }}$

Exist? $\underline{\mathbf{N}}(\mathrm{Y}$ or $N)$

Severity

Impact Severity: 0- none to very slight; 1- Slight; 2- Moderate; 3- Severe 
18. Bridge Type: 1a

1a- Vertical abutments with wingwalls

1 b- Vertical abutments without wingwalls

2- Vertical abutments and wingwalls, sloping embankment

Wingwalls perpendicular to abut. face

3- Spill through abutments

4- Sloping embankment, vertical wingwalls and abutments

Wingwall angle less than $90^{\circ}$.

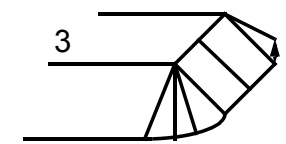
approach overflow width, etc.)

\#4: Right over-bank is cut grass with some residential homes.

\#5: Left bank includes shrub and brush and marsh upstream. Beyond 100 feet left of the left edge of water the surface cover is forest.

\section{Upstream Channel Assessment}

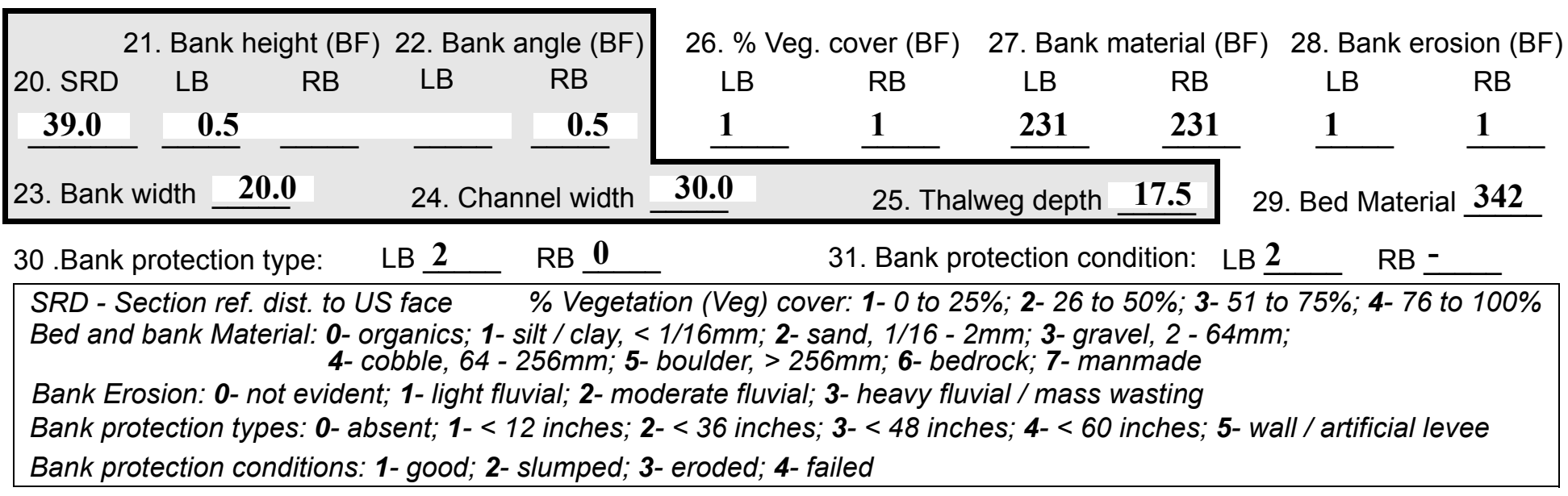

32. Comments (bank material variation, minor inflows, protection extent, etc.):

Beaver dam is 250 feet upstream.

Left bank protection extends from 24 feet upstream to 5 feet upstream. 
33.Point/Side bar present? $\mathbf{N}(Y$ or $N$. if $N$ type ctrl-n pb)34. Mid-bar distance: -

35. Mid-bar width:

36. Point bar extent: feet (US, UB) to feet (US, UB, DS) positioned $\%$ LB to $\% \mathrm{RB}$

37. Material:

38. Point or side bar comments (Circle Point or Side; Note additional bars, material variation, status, etc.):

NO POINT BARS

39. Is a cut-bank present? $\underline{\mathbf{N}}$ (Y or if $\mathrm{N}$ type ctrl-n cb)

40. Where? (LB or $R B)$

41. Mid-bank distance: -

42. Cut bank extent: feet (US, UB) to feet (US, UB, DS)

43. Bank damage: (1- eroded and/or creep; 2- slip failure; 3- block failure)

44. Cut bank comments (eg. additional cut banks, protection condition, etc.):

NO CUT BANKS

45. Is channel scour present? $\mathbf{Y}$ ( $Y$ or if $N$ type ctrl-n cs) $\quad$ 46. Mid-scour distance: 20

47. Scour dimensions: Length 15 Width $\underline{\mathbf{8}}$ Depth : $\underline{\mathbf{1}}$ Position $\underline{\mathbf{1 0}} \%$ LB to $\underline{\mathbf{9 0}} \% \mathrm{RB}$

48. Scour comments (eg. additional scour areas, local scouring process, etc.):

Thalweg is 1.5 feet.

49. Are there major confluences? $\mathbf{N}$ ( $Y$ or if $N$ type ctrl-n mc)

51. Confluence 1: Distance Confluence 2: Distance 52. Enters on (LB or $R B)$

Enters on (LB or $R B)$

54. Confluence comments (eg. confluence name):

NO MAJOR CONFLUENCES

Beaver dam has created many seeps along the left bank.

\section{Under Bridge Channel Assessment}

55. Channel restraint (BF)? LB 2 (1- natural bank; 2- abutment; 3- artificial levee)

\begin{tabular}{|cccc|cccc}
\hline \multicolumn{2}{l}{ 56. Height (BF) } & \multicolumn{2}{c}{57 Angle (BF) } & \multicolumn{2}{c}{ 61. Material (BF) } & \multicolumn{2}{c}{ 62. Erosion (BF) } \\
LB & RB & LB & RB & LB & RB & LB & RB \\
$\mathbf{1 5 . 5}$ & & & $\mathbf{1 . 5}$ & & & &
\end{tabular}

58. Bank width (BF) 59. Channel width (Amb) 60. Thalweg depth $(\mathrm{Amb}) \quad \mathbf{9 0 . 0}$ 63. Bed Material -

Bed and bank Material: 0- organics; 1- silt / clay, < 1/16mm; 2- sand, 1/16 - 2mm; 3- gravel, 2 - 64mm; 4- cobble, 64 - 256mm; 5- boulder, > 256mm; 6- bedrock; 7- manmade

Bank Erosion: 0- not evident; 1- light fluvial; 2- moderate fluvial; 3- heavy fluvial / mass wasting

64. Comments (bank material variation, minor inflows, protection extent, etc.):

3421 
65. Debris and Ice Is there debris accumulation?

(Yor $N)$ 66. Where? $\underline{Y}$

(1- Upstream; 2- At bridge; 3-Both)

67. Debris Potential 1 ( 1- Low; 2- Moderate; 3- High)

69. Is there evidence of ice build-up? 2

68. Capture Efficiency 2

(1-Low; 2- Moderate; 3- High)

Ice Blockage Potential $\mathbf{N}$

(1-Low; 2-Moderate; 3- High)

70. Debris and Ice Comments:

2

Beaver dam is upstream with some dead trees in pond area.

\begin{tabular}{|l|c|c|c|c|c|c|c|c|}
\hline Abutments & $\begin{array}{c}\text { 71. Attack } \\
\angle \text { (BF) }\end{array}$ & $\begin{array}{c}72 \text {. Slope } \angle \\
\text { (Qmax) }\end{array}$ & $\begin{array}{c}\text { 73. Toe } \\
\text { loc. (BF) }\end{array}$ & $\begin{array}{c}\text { 74. Scour } \\
\text { Condition }\end{array}$ & $\begin{array}{c}75 . \text { Scour } \\
\text { depth }\end{array}$ & $\begin{array}{c}\text { 76. Exposure } \\
\text { depth }\end{array}$ & 77. Material & 78. Length \\
\hline LABUT & & $\mathbf{1 0}$ & $\mathbf{9 0}$ & $\mathbf{2}$ & $\mathbf{2}$ & $\mathbf{0}$ & $\mathbf{7 . 0}$ & $\mathbf{9 0 . 0}$ \\
\hline RABUT & $\mathbf{1}$ & $\mathbf{0}$ & $\mathbf{9 0}$ & & & $\mathbf{2}$ & $\mathbf{2}$ & $\mathbf{4 1 . 5}$ \\
\hline
\end{tabular}

Pushed: $L B$ or RB

Toe Location (Loc.): 0- even, 1- set back, 2- protrudes

Scour cond.: 0- not evident; 1- evident (comment); 2- footing exposed; 3-undermined footing; 4- piling exposed; 5- settled; 6- failed

Materials: 1- Concrete; 2- Stone masonry or drywall; 3- steel or metal; 4- wood

79. Abutment comments (eg. undermined penetration, unusual scour processes, debris, etc.):

0

3.0

1

Left abutment footing begins 5 feet under bridge from upstream bridge face and extends to 0 feet downstream. The old stone abutment protruding into channel extends from 8 feet under bridge to 8 feet downstream.

Right abutment footing and old stone abutment extends from 15 feet under bridge from upstream bridge face to 13 feet downstream.

80. Wingwalls: $\begin{array}{llll} & & & \\ \text { Exist? Material? } & \text { Scour } & \text { Scour } & \text { Exposure } \\ \text { Condition? } & \text { depth? } & \text { depth? }\end{array}$

USLWW:
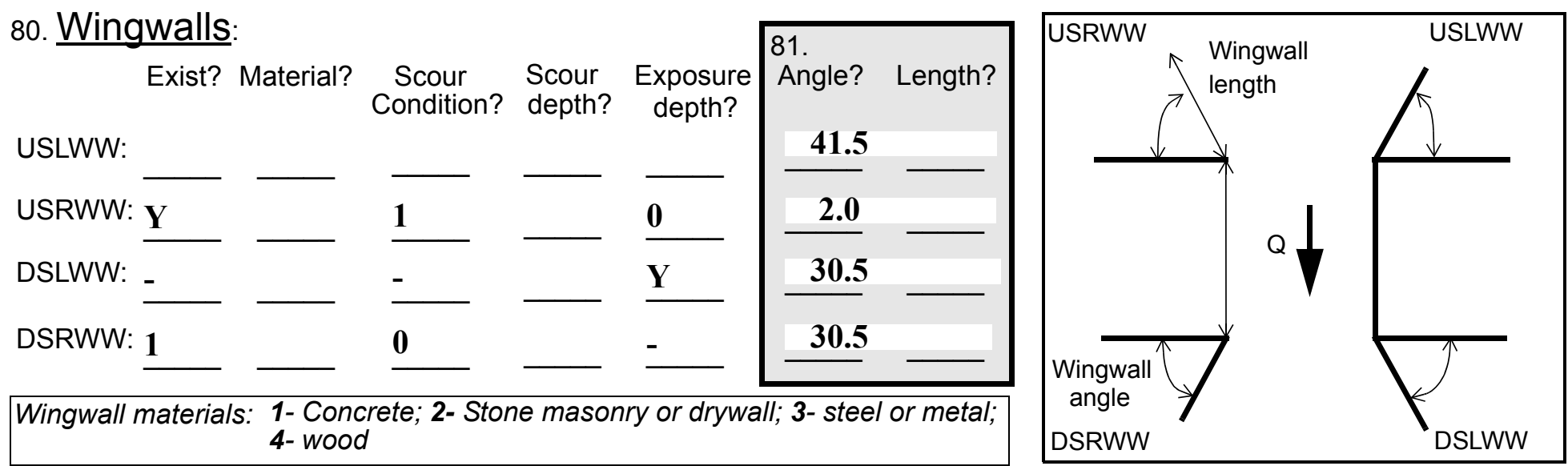

82. Bank / Bridge Protection:

\begin{tabular}{|l|l|l|l|l|l|l|l|c|}
\hline Location & USLWW & USRWW & LABUT & RABUT & LB & RB & DSLWW & DSRWW \\
\hline Type & - & $\mathbf{0}$ & $\mathbf{Y}$ & $\mathbf{0}$ & - & - & $\mathbf{3}$ & $\mathbf{1}$ \\
\hline Condition & $\mathbf{Y}$ & - & $\mathbf{1}$ & $\mathbf{4 . 0}$ & - & - & $\mathbf{4}$ & $\mathbf{4}$ \\
\hline Extent & $\mathbf{1}$ & - & $\mathbf{2}$ & $\mathbf{0}$ & $\mathbf{0}$ & $\mathbf{5}$ & $\mathbf{5}$ & - \\
\hline
\end{tabular}

Bank / Bridge protection types: 0- absent; 1- < 12 inches; 2- < 36 inches; 3- < 48 inches; 4- < 60 inches; 
83. Wingwall and protection comments (eg. undermined penetration, unusual scour processes, etc.):

-
-
-
-
-
5
1
1
5
1
1

\section{Piers:}

84. Are there piers? Th (Y or if $N$ type ctrl-n pr)

\begin{tabular}{|l|r|r|r|r|l|l|l|}
\hline \multirow{2}{*}{$\begin{array}{l}85 . \\
\text { Pier no. }\end{array}$} & \multicolumn{3}{|c|}{ width (w) feet } & \multicolumn{5}{c|}{ elevation (e) feet } \\
\cline { 2 - 9 } & w1 & w2 & w3 & e@w1 & e@w2 & e@w3 \\
\hline Pier 1 & & $\mathbf{8 . 5}$ & $\mathbf{4 . 5}$ & $\mathbf{4 0 . 0}$ & $\mathbf{1 1 0 . 0}$ & $\mathbf{1 1 0 . 0}$ \\
\hline Pier 2 & $\mathbf{4 . 0}$ & $\mathbf{5 . 0}$ & - & $\mathbf{7 5 . 0}$ & - & - \\
\hline Pier 3 & - & - & - & - & - & - \\
\hline Pier 4 & - & - & - & - & - & - \\
-
\end{tabular}

\begin{tabular}{|l|l|l|l|l|}
\hline Level 1 Pier Descr. & \multicolumn{1}{|c|}{1} & \multicolumn{1}{|c|}{2} & 3 & \multicolumn{1}{|c|}{} \\
\hline 86. Location (BF) & e old & to be & & - \\
\hline 87. Type & abut & abut & & - \\
\hline 88. Material & ment & ment & & - \\
\hline 89. Shape & s to a & pro- & & - \\
\hline 90. Inclined? & pre- & tec- & & - \\
\hline 91. Attack $\angle$ (BF) & vious & tion & & - \\
\hline 92. Pushed & struc & at & & - \\
\hline 93. Length (feet) & - & - & - & - \\
\hline 94. \# of piles & ture & this & N & - \\
\hline 95. Cross-members & are & site. & - & - \\
\hline 96. Scour Condition & con- & & - & - \\
\hline 97. Scour depth & sid- & & - & - \\
\hline 98. Exposure depth & ered & & - & - \\
\hline
\end{tabular}

LFP, LTB, LB, MCL, MCM, MCR, RB, RTB, RFP

1- Solid pier, 2- column, 3- bent

1-Wood; 2- concrete; 3- metal; 4- stone

1- Round; 2- Square; 3- Pointed

Y-yes; $N$ - no

$L B$ or $R B$

0- none; 1- laterals; 2- diagonals; 3- both

0- not evident; 1- evident (comment);

2- footing exposed; 3- piling exposed;

4- undermined footing; 5- settled; 6-failed 
99. Pier comments (eg. undermined penetration, protection and protection extent, unusual scour processes, etc.):

-
-
-
-
-
-
-
-
-

100.

\section{E. Downstream Channel Assessment}

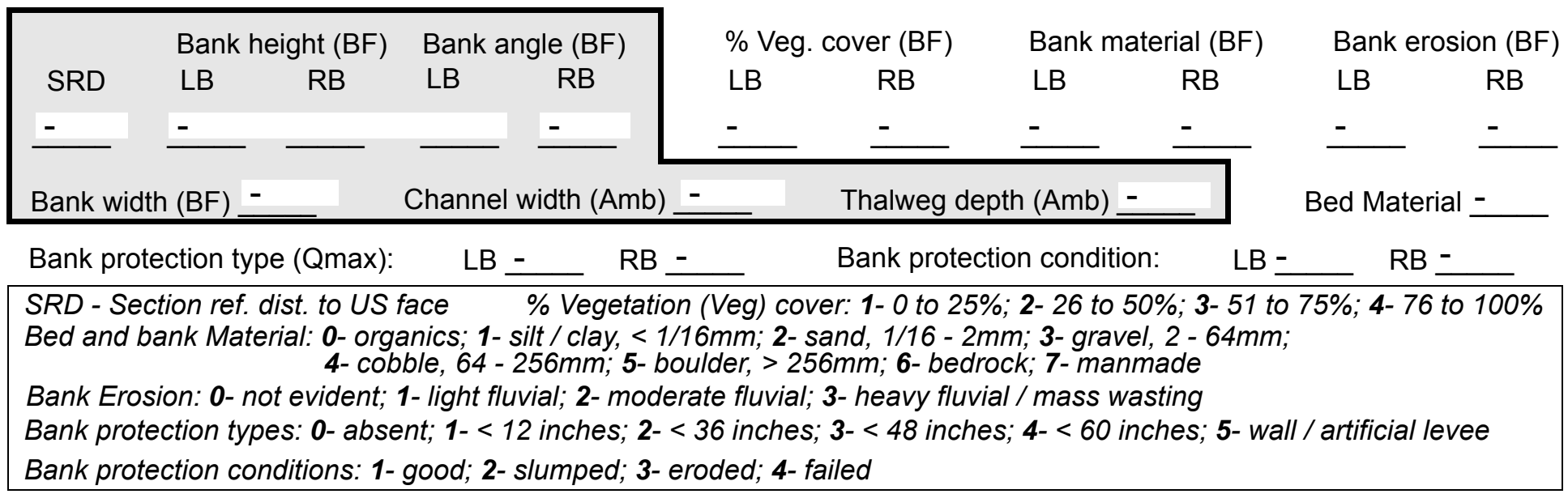

Comments (eg. bank material variation, minor inflows, protection extent, etc.):

-

NO PIERS

101. Is a drop structure present? ( $Y$ or $N$, if $N$ type ctrl-n $d s)$

102. Distance: feet

103. Drop: -_ feet 104. Structure material: (1- steel sheet pile; 2- wood pile; 3- concrete; 4- other)

105. Drop structure comments (eg. downstream scour depth): 
106. Point/Side bar present? 13 (Y or N. if N type ctrl-n pb)Mid-bar distance: $\mathbf{1 3}$

Mid-bar width: 2

Point bar extent: $\underline{\mathbf{0}}$ feet $\underline{32}$ (US, UB, DS) to $\underline{5}$ feet 5 (US, UB, DS) positioned $\underline{1}$ $\%$ LB to 1 $\%$ RB

Material: Lef

Point or side bar comments (Circle Point or Side; note additional bars, material variation, status, etc.):

t bank protection consists of the old abutment which extends from the bridge face to 8 feet downstream. Right bank protection consists of the old abutment which extends from bridge face to 13 feet downstream.

The confluence of Warm Brook and Fayville Branch is 526 feet downstream of bridge. A dam exists approxi-

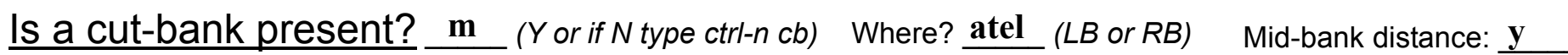
Cut bank extent: $\underline{770}$ feet feet (US, UB, DS) to dow feet nst (US, UB, DS)

Bank damage: rea (1- eroded and/or creep; 2- slip failure; 3- block failure)

Cut bank comments (eg. additional cut banks, protection condition, etc.):

$m$ of bridge.

Is channel scour present? ( $Y$ or if $N$ type ctrl-n cs)

Mid-scour distance:

Scour dimensions: Length Width Depth:

Positioned $\%$ LB to $\% \mathrm{RB}$ Scour comments (eg. additional scour areas, local scouring process, etc.):

$\mathbf{N}$

$-$

NO DROP STRUCTURE

Are there major confluences? ( $Y$ or if $N$ type ctrl-n $m c)$

How many?

Confluence 1: Distance Enters on ( $L B$ or $R B)$

Type $\underline{\mathbf{N}}$ (1-perennial; 2- ephemeral)

Confluence 2: Distance Enters on (LB or $R B)$

Type (1- perennial; 2- ephemeral)

Confluence comments (eg. confluence name):

\section{F. Geomorphic Channel Assessment}

107. Stage of reach evolution -

1- Constructed

2- Stable

3- Aggraded

4- Degraded

5- Laterally unstable

6- Vertically and laterally unstable 
108. Evolution comments (Channel evolution not considering bridge effects; See HEC-20, Figure 1 for geomorphic descriptors):

$-$

$-$

-

NO POINT BARS

Y

LB

60

12

DS

90 


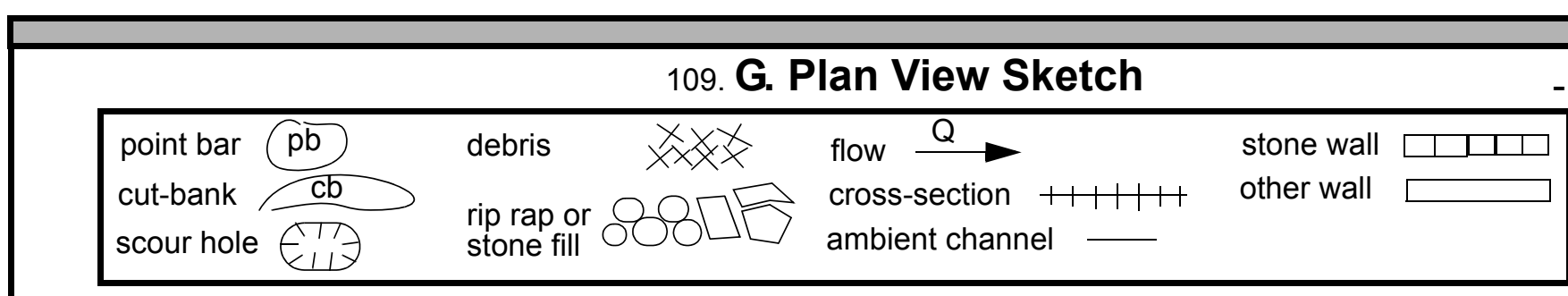

D 
APPENDIX F:

SCOUR COMPUTATIONS 


\begin{tabular}{|c|c|c|c|}
\hline $\begin{array}{ll}\text { Structure Number: ARLI004TH00010004 } \\
\text { Road Number: }\end{array}$ & & $\begin{array}{l}\text { Town: } \\
\text { County: }\end{array}$ & $\begin{array}{l}\text { ARLINGTON } \\
\text { BENNINGTON }\end{array}$ \\
\hline Stream: WARM BROOK & & & \\
\hline Initials SAO & Checked: & & \\
\hline alysis of contraction scour, live- & ed or $\mathrm{cl}$ & ear wat & \\
\hline $\begin{array}{l}\text { Critical Velocity of Bed Material } \\
\text { VC=11.21*y1^0.1667*D50^0.33 with } \mathrm{Ss} \\
\text { (Richardson and others, 1995, p. } 28\end{array}$ & $\begin{array}{l}\text { converted } \\
=2.65 \\
\text { eq. 16) }\end{array}$ & to Engl & sh units) \\
\hline Approach Section & & & \\
\hline Characteristic & $100 \mathrm{yr}$ & $500 \mathrm{yr}$ & other $\mathrm{Q}$ \\
\hline Total discharge, cfs & 2020 & 2730 & 900 \\
\hline Main Channel Area, ft2 & 150 & 155 & 127 \\
\hline Left overbank area, ft2 & 473 & 499 & 363 \\
\hline Right overbank area, ft2 & 1173 & 1302 & 634 \\
\hline Top width main channel, ft & 17 & 17 & 17 \\
\hline Top width L overbank, ft & 89 & 91 & 83 \\
\hline Top width $\mathrm{R}$ overbank, ft & 440 & 444 & 395 \\
\hline D50 of channel, ft & 0.109 & 0.109 & 0.109 \\
\hline D50 left overbank, ft & -- & -- & -- \\
\hline D50 right overbank, ft & -- & -- & -- \\
\hline Y1, average depth, MC, ft & 8.8 & 9.1 & 7.5 \\
\hline Y1, average depth, LOB, ft & 5.3 & 5.5 & 4.4 \\
\hline $\mathrm{y}_{1}$, average depth, ROB, ft & 2.7 & 2.9 & 1.6 \\
\hline Total conveyance, approach & 121054 & 138098 & 61152 \\
\hline Conveyance, main channel & 18083 & 19117 & 13829 \\
\hline Conveyance, LOB & 26582 & 28777 & 17940 \\
\hline Conveyance, ROB & 76390 & 90204 & 29383 \\
\hline Percent discrepancy, conveyance & -0.0008 & 0.0000 & 0.0000 \\
\hline Qm, discharge, MC, cfs & 301.7 & 377.9 & 203.5 \\
\hline Q1, discharge, LOB, Cfs & 443.6 & 568.9 & 264.0 \\
\hline Qr, discharge, ROB, cfs & 1274.7 & 1783.2 & 432.4 \\
\hline $\mathrm{Vm}$, mean velocity $\mathrm{MC}$, ft/s & 2.0 & 2.4 & 1.6 \\
\hline $\mathrm{Vl}$, mean velocity, LOB, ft/s & 0.9 & 1.1 & 0.7 \\
\hline Vr, mean velocity, ROB, ft/s & 1.1 & 1.4 & 0.7 \\
\hline Vc-m, crit. velocity, MC, ft/s & 7.7 & 7.7 & 7.5 \\
\hline Vc-l, crit. velocity, LOB, ft/s & ERR & ERR & $\mathrm{ERR}$ \\
\hline Vc-r, crit. velocity, ROB, ft/s & $\mathrm{ERR}$ & ERR & $\mathrm{ERR}$ \\
\hline Results & & & \\
\hline Live-bed(1) or Clear-Water(0) Contr & action $\mathrm{Sc}$ & our? & \\
\hline Main Channel & 0 & 0 & 0 \\
\hline Left Overbank & $\mathrm{N} / \mathrm{A}$ & $\mathrm{N} / \mathrm{A}$ & $\mathrm{N} / \mathrm{A}$ \\
\hline Right Overbank & $\mathrm{N} / \mathrm{A}$ & $\mathrm{N} / \mathrm{A}$ & $\mathrm{N} / \mathrm{A}$ \\
\hline
\end{tabular}




$\begin{array}{llll}\text { ARMORING } & & & \\ \text { D90 } & 0.299 & 0.299 & 0.299 \\ \text { D95 } & 0.959 & 0.959 & 0.959 \\ \text { Critical grain size,Dc, ft } & 0.2584 & 0.3788 & 0.1692 \\ \text { Decimal-percent coarser than DC } & 0.133 & 0.0814 & 0.273 \\ \text { Depth to armoring,ft } & 5.05 & 12.82 & 1.35\end{array}$

Clear Water Contraction Scour in MAIN CHANNEL

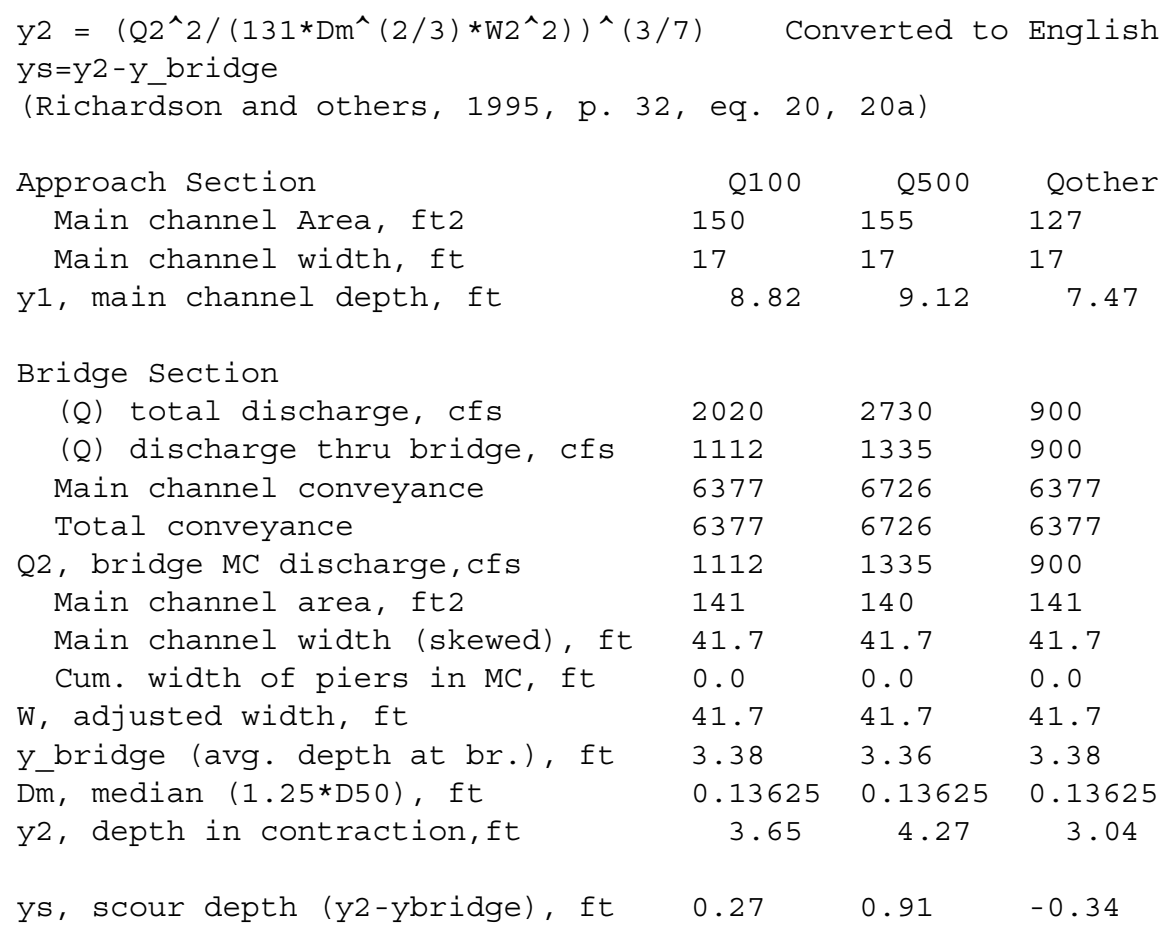

Pressure Flow Scour (contraction scour for orifice flow conditions)

\begin{tabular}{|c|c|c|c|c|}
\hline $\mathrm{Hb}+\mathrm{Ys}=\mathrm{Cq} * \mathrm{qb} r / \mathrm{Vc}$ & & $C f=1$. & $\overbrace{}^{\wedge} 0.43$ & $(<=1)$ \\
\hline Chang Equation & o ( $\mathrm{Hb} /(\mathrm{ya}$ & v) -0.56 & -0.79 & $(<=1)$ \\
\hline (Richarson and others, 1995, p. 145 & $-146)$ & & & \\
\hline & Q100 & Q500 & OtherQ & \\
\hline Q, total, cfs & 2020 & 2730 & 900 & \\
\hline Q, thru bridge, cfs & 1112 & 1335 & 900 & \\
\hline Total Conveyance, bridge & 6377 & 6726 & 6377 & \\
\hline Main channel (MC) conveyance, bridge & 6377 & 6726 & 6377 & \\
\hline Q, thru bridge $\mathrm{MC}$, Cfs & 1112 & 1335 & 900 & \\
\hline Vc, critical velocity, ft/s & 7.70 & 7.74 & 7.49 & \\
\hline Vc, critical velocity, m/s & 2.35 & 2.36 & 2.28 & \\
\hline Main channel width (skewed), ft & 41.7 & 41.7 & 41.7 & \\
\hline Cum. width of piers in MC, ft & 0.0 & 0.0 & 0.0 & \\
\hline w, adjusted width, ft & 41.7 & 41.7 & 41.7 & \\
\hline qbr, unit discharge, ft2/s & 26.7 & 32.0 & 21.6 & \\
\hline qbr, unit discharge, $\mathrm{m} 2 / \mathrm{s}$ & 2.5 & 3.0 & 2.0 & \\
\hline Area of full opening, ft2 & 141.0 & 140.0 & 141.0 & \\
\hline $\mathrm{Hb}$, depth of full opening, ft & 3.38 & 3.36 & 3.38 & \\
\hline $\mathrm{Hb}$, depth of full opening, m & 1.03 & 1.02 & 1.03 & \\
\hline Fr, Froude number, bridge $\mathrm{MC}$ & 0.78 & 0.95 & 0.62 & \\
\hline
\end{tabular}




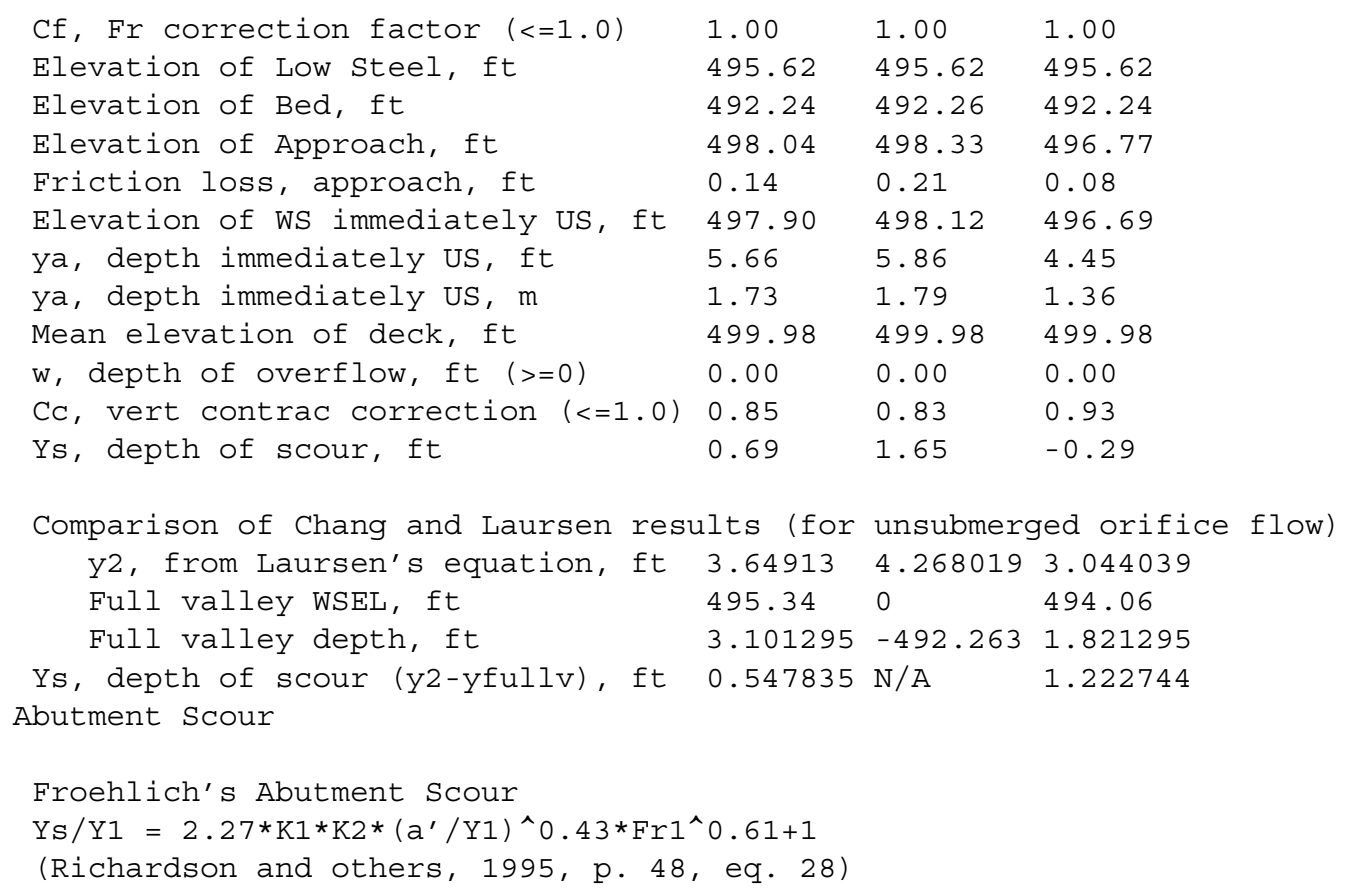




\begin{tabular}{|c|c|c|c|c|c|c|}
\hline \multicolumn{7}{|c|}{$\begin{array}{l}\text { Isbash Relationship } \\
\mathrm{D} 50=\mathrm{Y}^{\star} \mathrm{K} * \mathrm{Fr} r^{\wedge} 2 /(\mathrm{Ss}-1) \text { and } \mathrm{D} 50=\mathrm{Y}^{*} \mathrm{~K} *\left(\mathrm{Fr} r^{\wedge} 2\right)^{\wedge} 0.14 /(\mathrm{Ss}-1) \\
\text { (Richardson and others, 1995, p112, eq. 81,82) }\end{array}$} \\
\hline Characteristic & Q100 & Q500 & Qothe & & & \\
\hline $\begin{array}{l}\text { Fr, Froude Number } \\
\text { (Fr from the characteristic } V \text { and }\end{array}$ & $\begin{array}{l}0.78 \\
y \text { in }\end{array}$ & $\begin{array}{l}0.95 \\
\text { tracte }\end{array}$ & $\begin{array}{l}0.62 \\
\text { section }\end{array}$ & $\begin{array}{l}0.78 \\
\text { c, bri }\end{array}$ & $\begin{array}{l}0.95 \\
\text { secti }\end{array}$ & 0.62 \\
\hline$y$, depth of flow in bridge, ft & 3.38 & 3.36 & 3.38 & 3.38 & 3.36 & 3.38 \\
\hline \multicolumn{4}{|c|}{ Median Stone Diameter for riprap at: left abutment } & \multicolumn{3}{|c|}{ right abutment, ft } \\
\hline Fr $<=0.8$ (vertical abut.) & 1.27 & ERR & 0.80 & 1.27 & ERR & 0.80 \\
\hline Fr>0.8 (vertical abut.) & ERR & 1.38 & ERR & ERR & 1.38 & ERR \\
\hline Fr<=0.8 (spillthrough abut.) & 1.11 & ERR & 0.70 & 1.11 & ERR & 0.70 \\
\hline Fr>0.8 (spillthrough abut.) & ERR & 1.22 & ERR & ERR & 1.22 & $\mathrm{ERR}$ \\
\hline
\end{tabular}

